\title{
Serum uric acid levels as an indicator for metabolically unhealthy obesity in children and adolescents
}

\author{
Dissertation \\ zur Erlangung des akademischen Grades
}

Dr. rer. med.

an der Medizinischen Fakultät

der Universität Leipzig

eingereicht von: $\quad$ Edrienny Patrícia Alves Accioly Rocha, M.Sc.

geboren am 10.07.1984 in Recife (Brasilien)

angefertigt an: $\quad$ Universität Leipzig, Medizinische Fakultät, Klinik und Poliklinik für Kinder und Jugendliche, in Zusammenarbeit mit dem Leipziger Forschungszentrum für Zivilisationserkrankungen (LIFE)

Betreuer von: $\quad$ Prof. Dr. med. Wieland Kiess

Dr. rer. med. Mandy Vogel

Beschluss über die Verleihung des Doktorgrades vom: 18.12.2018 


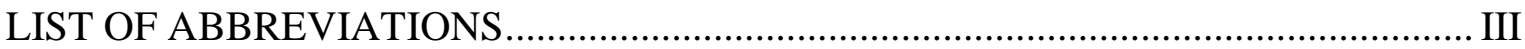

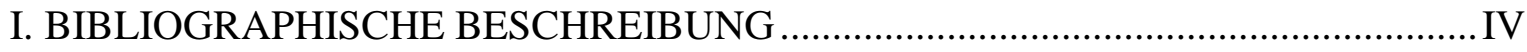

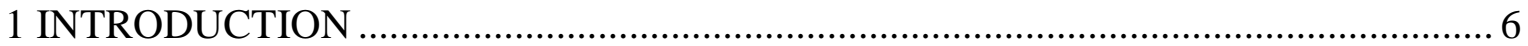

1.1 Obesity and associated diseases, a world health threat........................................ 7

1.1.1 Definitions and classifications of overweight and obesity ..................... 8

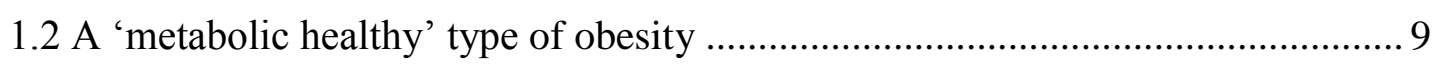

1.2.1 Distinguishing characteristics of healthy obesity ................................ 12

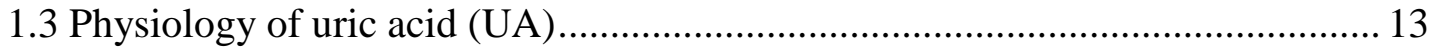

1.3.1 Serum UA and cardiometabolic risk factors ...................................... 14

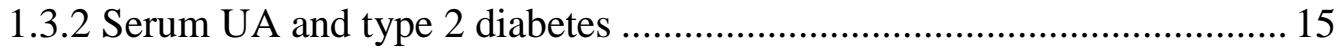

1.3.3 Serum UA and hypertension........................................................... 16

1.3.4 Serum UA and kidney-related complications ..................................... 17

1.3.5 Connection between Serum UA levels and metabolic health status........ 17

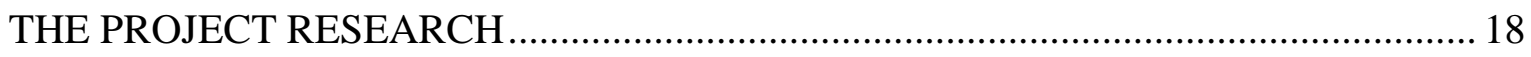

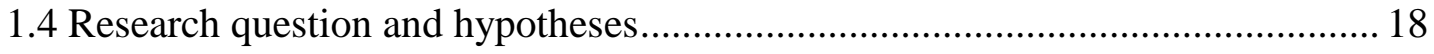

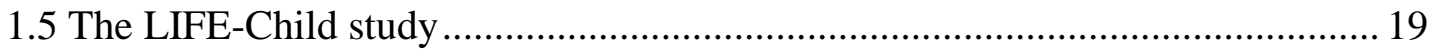

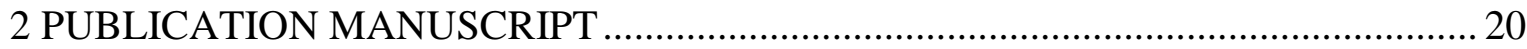

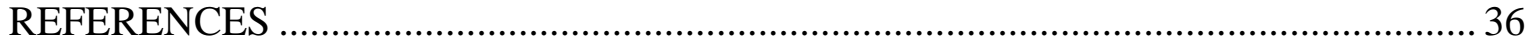

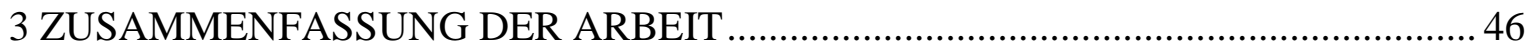

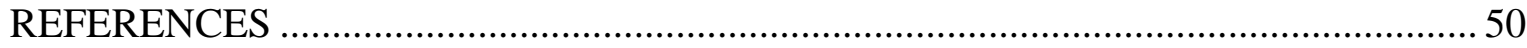

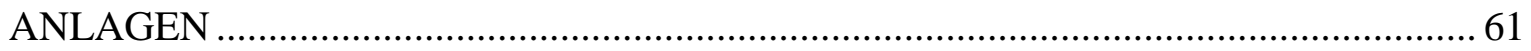

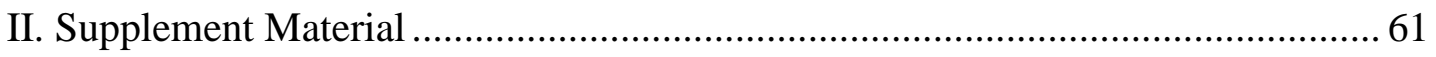

III. Erklärung über die eigenständige Abfassung der Arbeit .................................... 64

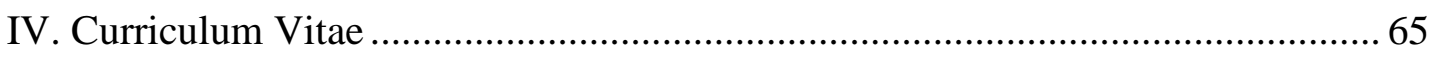

V. List of publications and conference participations ...............................................6 67

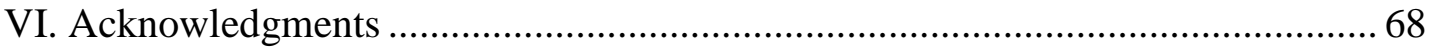




\section{LIST OF ABBREVIATIONS}

BMI Body mass index

BP Blood pressure

CVD Cardiovascular disease

HDL-C High density lipoprotein cholesterol

Hs-CRP High sensitivity C-reactive protein

IDF International diabetes federation

IR Insulin resistance

KiGGS Kinder- und Jugendgesundheitssurvey (German Health Interview and Examination Survey for Children and Adolescents)

FPG Fasting plasma glucose

HDL-c High density lipoprotein cholesterol

HOMA-IR Homeostasis model assessment of insulin resistance

LIFE Leipzig Research Center for Civilization Diseases

MS Metabolic syndrome

MHO Metabolically healthy obesity

MUO Metabolically unhealthy obesity

NCEP National Cholesterol Education Program

TG Triglycerides

UA Uric acid

WC Waist circumference

WHO World Health Organization 


\section{BIBLIOGRAPHISCHE BESCHREIBUNG}

Edrienny Patrícia Alves Accioly Rocha

\section{Serum uric acid levels as an indicator for metabolically unhealthy obesity in children and adolescents}

Universität Leipzig, Dissertation

69 Seiten, 109 Literaturangaben, 6 Tabellen, 1 Publikationsmanuskript

\section{Referat:}

Adipositas im Kindes- und Jugendalter erhöht das Risiko für diverse chronische Krankheiten und ist aufgrund des epidemischen Anteils weltweit zu einem der größten Gesundheitsprobleme geworden. Zunehmende Evidenz zeigt, dass übergewichtige Personen, die unter "metabolisch gesunder Fettleibigkeit (MHO)" leiden, gegen Typ 2Diabetes mellitus und kardiovaskulären Erkrankungen geschützt sind - im Gegensatz $\mathrm{zu}$ denen mit einer "metabolisch ungesunden Fettleibigkeit" (MUO). Jüngste Studien deuten darauf hin, dass neue Biomarker erfolgreich verwendet werden könnten, um den MHO- vom MUO-Phänotyp zu unterscheiden. Erhöte Serumharnsäurespiegel wurde als potentieller Risikofaktor für kardiometabolische Erkrankungen beschrieben, aber bisher haben nur wenige Studien deren Beziehung zu MHO und MUO innerhalb der pädiatrischen Population untersucht. In der vorliegenden Studie wurden die potenziellen klinischen und metabolischen Indikatoren, die zur Unterscheidung zwischen MHO- und MUO-Phänotypen bei Kindern und Jugendlichen beitragen können, anhand von Daten aus einer Studie in Deutschland ausgewertet, im Rahmen derer Daten von 246 übergewichtigen und adipösen und 212 normalgewichtigen Kindern und Jugendlichen erhoben wurden. Dieselben Daten wurden verwendet, um die Beziehung zwischen Serum-Harnsäure-Spiegeln und der metabolischen Gesundheit bei übergewichtigen und adipösen Kindern und Jugendlichen $\mathrm{zu}$ untersuchen. Eine umfassende anthropometrische, klinische und metabolische Charakterisierung des metabolischen Profils von MHO- und MUO-Phänotypen ist verfügbar. Diese Studie ergab, dass $70 \%$ der übergewichtigen und adipösen Teilnehmer einen MHO-Status hatten. Der MHOPhänotyp war im Allgemeinen durch eine bessere Insulinsensitivität, niedrigere Triglycerid (TG)-Spiegel und einen niedrigeren High Density Lipoprotein Cholesterol(HDL-c) im Vergleich zu ihren MUO-Peers charakterisiert. Es wurde gezeigt, dass Serumharnsäure mit Parametern verbunden ist, die zur Definition des metabolischen 
Gesundheitszustands verwendet werden, wie HDL-SDS, TG-SDS, Nüchternglukose und Blutdruck. Zusätzlich schien die Serumharnsäure-Konzentration mit C-Peptid- und Cystatin C-Konzentrationen assoziiert zu sein. Das in dieser Arbeit vorgestellte Forschungsergebnis legt nahe, dass höhere Harnsäurespiegel als zusätzlicher Indikator für den MUO-Phänotyp bei übergewichtigen und adipösen Kindern und Jugendlichen verwendet werden könnten. 
1 INTRODUCTION

"Corpulence is not only a disease itself, but the harbinger of others."

Hippocrates 


\subsection{Obesity and associated diseases, a world health threat}

Obesity is associated with higher incidence of many health problems including cardiovascular diseases, type 2 diabetes and several types of cancer [1,2]. These complications contribute to a higher likelihood of morbidity and mortality in adulthood [3]. At the same time, the current obesity epidemic, which has spread from western to developing countries, is affecting even younger individuals. In fact, over the past decades, the proportion of overweight and obese children and adolescents has soared globally, rendering youth obesity a major focus of public health efforts [4]. A systematic review showed that between 1980 and 2013 the prevalence of overweight and obesity in children has increased by $47.1 \%$ worldwide [5]. Although recent studies conducted in several developed countries suggest a stabilization trend in the prevalence of obesity, especially among younger children, its prevalence in adolescents continues to increase [1,6]. In 2006, evaluating a sample of more than 17,500 young individuals (2-17 years), the German Health Interview and Examination Survey for Children and Adolescents (KiGGS) estimated that $15 \%$ of German children and adolescents were overweight and $6.1 \%$ were obese $[1,7]$. Globally, the prevalence of childhood obesity is particularly high in Latin America (Mexico, Brazil, Chile, Uruguay and Argentina), North Africa, the Middle East, India, and several Pacific Island and Caribbean nations [5,8].

The primary pathway linking overweight and obesity to the development of diseases is dysregulated metabolism, which is related to long-term inefficiencies in balancing intake and use of energy in the body [9]. As the prevalence of childhood and adolescence obesity increases, its health implications are becoming more evident. Obesity developed during childhood and adolescence instigates changes in metabolism, vessels and organs, thereby increasing the risk of severe cardiometabolic complications and premature death [10]. A certain combination of such abnormalities is known as metabolic syndrome (MS) and is characterized by high blood pressure, insulin resistance, unfavorable lipid profile (high levels triglycerides and/or low levels of cholesterol bound to high-density lipoprotein), liver enzymes alterations, abnormalities in fibrinolysis, subclinical inflammation and hyperuricemia. The metabolic syndrome has been used to link obesity and cardiovascular disease (CVD) risk factors [11,12]. Some studies have reported clustering of CVD risk factors among obese children and adolescents and a positive relationship between the level of overweight and the prevalence of the metabolic syndrome. A relationship between metabolic syndrome during childhood and the risk of CVD has also been observed later life. 
In addition, excess body fat has been associated with increased risk of musculoskeletal conditions and obstructive sleep apnea, chronic pain, asthma and gallbladder [17].

These effects can reduce quality of life of affected individuals while also placing a substantial economic burden on health and social care systems [18]. In 2007, according to the World Health Organization, overweight and obesity were linked to about $80 \%$ of type 2 diabetes cases, $35 \%$ of ischemic heart disease cases and 55\% of hypertension cases among adults in Europe. These complications result in more than 12 million life-years of health problems and 1 million deaths per year. In Germany, cardiovascular diseases were estimated to cause $39 \%$ of all deaths [19]. The treatment costs for cardiovascular diseases were 37.4 billion $€$ in 2014 (equivalent to $1.4 \%$ of the gross domestic product GDP) and are projected to amount to 41.4 billion in 2020 [20].

Despite the substantial progress in research during the last decades, obesity is still difficult to manage. In fact, the extent of fat accumulation, its distribution within the body and the associated consequences vary considerably between individuals [21]. It is estimated that up to $30 \%$ of obese individuals do not have obesity-related comorbidities and do not show any evidence of metabolic abnormalities. Consequently, they have a reduced risk of developing type 2 diabetes mellitus and cardiovascular disease [22]. This subgroup is identified as metabolically healthy obese (MHO). However, it is unclear how healthy the individuals of this group are and whether MHO could later develop into metabolically unhealthy obesity (MUO) [23]. An improved understanding of the underlying mechanisms and the health consequences of different obese phenotypes in youth could represent the first step towards the prevention of an array of deleterious chronic diseases that commonly emerge throughout the life-course and may lead to a beneficial healthy aging process. Considering the variability of individuals within the obese population, it would be useful to allocate them into more specific groups according to their degree of metabolic abnormalities, aiming at early diagnoses and successful treatments, in order to be able to address their needs more specifically [24].

\subsubsection{Definitions and classifications of overweight and obesity}

Overweight and obesity are defined as an abnormal or excessive accumulation of body fat that poses a health risk [25]. The most commonly used, widely accepted, inexpensive and non-invasive indicator for the level of adiposity is the body mass index (BMI, expressed as 
weight $/$ height $^{2}$ in $\mathrm{kg} / \mathrm{m}^{2}$ ). BMI has been criticized for not being sensitive enough to detect differences in body composition (i.e. fat mass and fat-free mass) [26]. Nevertheless, it is a simple and practical method to use. Adults ( $\geq 18$ years) with a BMI $\geq 25 \mathrm{~kg} / \mathrm{m}^{2}$ are classified as overweight and those with a BMI $\geq 30 \mathrm{~kg} / \mathrm{m}^{2}$ are classified as obese [27]. Regarding children and adolescents, however, growth and development at different ages have to be taken into account and, therefore, BMI cut-offs used for adults cannot be used. Although BMI and fat mass of adults and youths are closely correlated [26], assessing adiposity for young individuals is more complicated, as the fat mass changes with age, gender, maturation and ethnicity [28]. In addition, to be able to compare weight status between groups of children, the definition of childhood overweight and obesity is based on age and sex-specific BMI cut-off values - presented in tables or pointed out as centiles on a chart - which are generally derived from representative reference population.

\subsection{A 'metabolic healthy' type of obesity}

The heterogeneity of the healthy obese phenotype was first described in the 1980s by Sims [29] and has repeatedly been confirmed since then [30,31]. Analyses of epidemiological data concluded that overweight and obesity are not always associated with the onset of cardiovascular disease and increased mortality [32]. Research has focused on disentangling the underlying mechanisms that protect obese individuals from metabolic diseases [33]. In a follow-up study covering 10 years, Mongraw-Chaffin et al. [34] observed that $24 \%$ of obese individuals were metabolically healthy and did not develop metabolic syndrome. This means that 1 out of 4 individuals who have been obese over long period will not develop metabolic complications.

The main metabolic characteristics of MHO individuals have been reported to be a set of favorable metabolic profiles, such as: preserved insulin sensitivity, absence of metabolic syndrome criteria, low serum uric acid levels, low inflammatory indicators, favorable lipid, immunological and hormonal profiles, and low visceral, hepatic, and muscle fat accumulation. However, up to now, little is known about the factors that either delay the onset of metabolic disturbances or protect obese individuals from them [35]. Consequently, numerous systems have been developed to classify the clustering and the severity of metabolic risks associated with obesity.

Currently, overweight or obese individuals can be classified as metabolically healthy obese, according to three definitions: $(i)$ the determination of metabolic risk factor clustering (e.g. 
favorable lipid profile, normal glycemic status, and the normal blood pressure), (ii) a preserved insulin sensitivity, and (iii) the combination of the previous two definitions. Nevertheless, there is evidence that the above-mentioned definitions should be broadened by considering additional components, such as serum uric acid, inflammation markers and liver fat content [36,37]. Insulin sensitivity is predominantly assessed by using the surrogate homeostasis model assessment of insulin resistance (HOMA-Index) with subjective cut-offs. For instance, Prince et al. [38] defined MHO as the absence of insulin resistance (IR), a wellestablished predictor of type 2 diabetes, or as the absence of four traditional cardiovascular risk factors: high triglycerides, low HDL cholesterol, high fasting glucose and high blood pressure percentile for age, sex and height. Camhi et al. [39] define MHO as showing at least one of the following metabolic risk factors: high blood pressure, high triglycerides, high fasting glucose, low HDL cholesterol. A study that evaluated data from German obese children, defined $\mathrm{MHO}$ as the absence of hypertension, dyslipidemia and impaired fasting glucose [40]. Finally, two studies used metabolic syndrome criteria proposed earlier by Alberti et al. and defined MHO as waist circumference $\leq 90^{\text {th }}$ percentile together with no laboratory criterium of metabolic syndrome definition fulfilled [37,41]. MHO in children and adolescents is often defined using the pediatric International Diabetes Federation (IDF) criteria [39], the modified NCEP III criteria [42] and the age specific criteria [43] for the definition of metabolic syndrome. However, there is still no consensus regarding the number of metabolic syndrome criteria that must not be fulfilled to consider obese children and adolescent as metabolically healthy. A general overview of criteria sets that have been used to define MHO in children and adolescents is presented in Box $\mathbf{1 .}$ 
Box 1. Variables and values used for the definitions of MHO in pediatric population.

\begin{tabular}{|c|c|c|c|c|c|}
\hline Variables & $\begin{array}{c}\text { Prince RL } \\
\text { et al } 2014 \\
{[38]}\end{array}$ & $\begin{array}{c}\text { Camhi SM } \\
\text { et al } 2013 \text { [39] }\end{array}$ & $\begin{array}{c}\text { Reinehr T et al } \\
2015[40]\end{array}$ & $\begin{array}{c}\text { Mangge H } \\
\text { et al } 2013 \text { [37] }\end{array}$ & $\begin{array}{l}\text { Weghuber D } \\
\text { et al, } 2013 \text { [41] }\end{array}$ \\
\hline $\mathbf{W C}$ & & & & $\geq 90$ th percentile & $\geq 90$ th percentile \\
\hline BP & $\begin{array}{c}\quad \geq 90 \text { th } \\
\text { percentile for } \\
\text { age, sex, and } \\
\text { height }\end{array}$ & $\begin{array}{l}\quad \geq 90 \text { th } \\
\text { percentile for } \\
\text { age, gender, } \\
\text { and height }\end{array}$ & $\begin{array}{c}\geq 130 / 85 \\
\mathrm{mmHg}\end{array}$ & $\geq 130 / 85 \mathrm{mmHg}$ & $\geq 130 / 85 \mathrm{mmHg}$ \\
\hline FPG & $\begin{array}{c}\geq 5.6 \\
\mathrm{mmol} / \mathrm{L} .\end{array}$ & $\geq 100 \mathrm{mg} / \mathrm{dL}$ & $\geq 100 \mathrm{mg} / \mathrm{dl}$ & $\geq 5.6 \mathrm{mmol} / \mathrm{L}$. & $\geq 5.6 \mathrm{mmol} / \mathrm{L}$ \\
\hline TG & $\begin{array}{l}\geq 1.25 \\
\mathrm{mmol} / \mathrm{L}\end{array}$ & $\geq 110 \mathrm{mg} / \mathrm{dL}$ & $150 \mathrm{mg} / \mathrm{dl}$ & $\geq 1.7 \mathrm{mmol} / \mathrm{L}$ & $\geq 1.7 \mathrm{mmol} / \mathrm{L}$ \\
\hline HDL-cM & $\begin{array}{c}\leq 1.02 \\
\mathrm{mmol} / \mathrm{L}\end{array}$ & $<40 \mathrm{mg} / \mathrm{dL}$ & $<40 \mathrm{mg} / \mathrm{dl}$ & $<1.03 \mathrm{mmol} / \mathrm{L}$ & $<1.03 \mathrm{mmol} / \mathrm{L}$ \\
\hline HOMA-IR & $\geq 3.16$ & & & & \\
\hline $\begin{array}{c}\text { Criteria for } \\
\text { MHO }\end{array}$ & $\begin{array}{c}\text { None of the } \\
\text { above }\end{array}$ & $\begin{array}{c}\leq 1 \text { of the } \\
\text { above }\end{array}$ & $\begin{array}{c}\text { None of the } \\
\text { above }\end{array}$ & $\begin{array}{c}\text { None of the } \\
\text { above }\end{array}$ & $\begin{array}{c}\text { None of the } \\
\text { above }\end{array}$ \\
\hline MUO criteria & $\begin{array}{c}\geq \text { lof the } \\
\text { above }\end{array}$ & $\geq 2$ of the above & $\begin{array}{c}\geq 1 \text { of the } \\
\text { above }\end{array}$ & $\begin{array}{c}\geq 3 \text { of the } \\
\text { above }\end{array}$ & $\begin{array}{c}\geq 3 \text { of the } \\
\text { above }\end{array}$ \\
\hline \multicolumn{6}{|c|}{ BMI (percentile) } \\
\hline & $>85^{\text {th }}$ & $>95^{\text {th }}$ & $>97^{\text {th }}$ & $\begin{array}{c}\text { Overweight }>85^{\text {th }} \\
\text { Obese }>95^{\text {th }}\end{array}$ & $\begin{array}{c}\text { Overweight } \\
\quad>85^{\text {th. }} \\
\text { Obese }>95^{\text {th }}\end{array}$ \\
\hline \multicolumn{6}{|c|}{$\begin{array}{l}\text { WC: waist circumference; BP: blood pressure; FPG: fasting plasma glucose; TG: triglyceride; HDL: high density lipoprotein; } \\
\text { HOMA-IR: homeostasis model assessment of insulin resistance; MHO: metabolically healthy obesity; MUO: metabolically } \\
\text { unhealthy obesity; BMI: body mass index. }\end{array}$} \\
\hline
\end{tabular}


Although MHO in the adult population has been extensively studied, research focusing on children and adolescents is scarce. Based on diverse criteria, a recent review reported an MHO prevalence in obese children ranging from 18 to 44\% [44]. The broad range was attributed to geographic distribution, age, sample size differences, different study design and different definitions used for obesity and metabolic health. Rey-Lopez et al. showed an even higher variability of MHO prevalence from $6 \%$ to $75 \%$ reported in various publications [45]. A recent study conducted in Chinese children and adolescents aged 6- to 18-years-old found prevalence of MHO was 3.9\%-36.7\%, using two different MHO criteria defined by insulin resistance and metabolic syndrome components respectively [22]. Data from a recently published longitudinal German study, based on a population of obese children, suggested that a substantial proportion of young obese (49.3\%) displays an MHO phenotype [40]. The high variability of MHO prevalence in the aforementioned studies is due to the fact that the definition of MHO is still controversial and that no clear criteria have been widely accepted. Accumulating evidence indicates that different factors, including lifestyle, sex, age, ethnicity and specific cut-off values can largely influence the MHO prevalence [46]. Therefore, without a wide consensus on the definition of MHO individuals, the comparability between different studies and the successful interpretation of the association between MHO and longterm health effects remain difficult to achieve.

\subsubsection{Distinguishing characteristics of healthy obesity}

Although the underlying mechanisms leading to the transition between healthy and unhealthy obese phenotypes are poorly understood, several plausible mechanisms have been suggested in both human and animal studies [24,35,47]. Therefore, it is of great interest to identify additional biomarkers that distinguish between healthy and unhealthy overweight or obese individuals. This indicators might be useful to understand the mechanisms and the predisposing factors linking metabolic disorders to obesity [48] and could become relevant tools for identifying future diseases and to make accurate prognoses. Over the last years, several biomarkers have been proposed to distinguish different phenotypes of obesity. A biomarker of growing importance is serum uric acid: high levels of uric acid have been reported to be a clinically essential cue for inflammations, which are linked to metabolic disorders in seemingly healthy individuals [49]. Weghuber et al. [41] examined 299 overweight/obese children and adolescents and showed that serum uric acid levels were a significant predictor of metabolically unhealthy obesity (MUO) in youth populations. Other 
inflammation markers, such as high-sensitivity $\mathrm{C}$ reactive protein (hs-CRP), may also be an important component in the cluster of metabolic risk factors [50]. Phillips and Perry [51] demonstrated that MHO individuals presented a more favorable inflammatory status than their metabolically unhealthy counterparts, including lower concentrations of hs-CRP, interleukin 6 and white blood cell count. It has been increasingly suggested to include liver fat content in the definition of $\mathrm{MHO}$, because the prevalence of non-alcoholic fatty liver disease seems to be significantly lower in MHO individuals [52]. Recently, C-peptide was discovered to be a part of the immune response by regulating inflammatory cytokines and was associated with MS components [53,54]. This finding suggests that C-peptide concentrations might also be a clinically relevant indication of cardiovascular risk associated with metabolic disorders [54]. The exact attributes of additional biomarkers characterizing different obesity phenotypes have yet to be defined. There is growing scientific and medical interest in the MHO subgroup as ramifications of the health-preserving characteristics could individualize our current knowledge of chronic disease development [35].

\subsection{Physiology of uric acid (UA)}

Uric acid was first found in human urinary calculi by Scheele and Bergmann in 1776 $[55,56]$. They named the substance lithic acid and proved that it is a common urine component. In 1798 George Pearson, after isolating and characterizing uric acid from 200 urinary calculi specimens, suggested the name uric oxide [57]. The structure of uric acid was first proposed by Ludwig Medicus in 1875 [55,58]. Finally, after the pioneering works by Medicus, Liebig, and von Baeyer, the complete synthesis of uric acid was successfully performed for the first time in 1895 by the future Nobel laureate Emil Fischer [59,60].

Uric acid is a breakdown product of ingested and endogenously synthesized purines. DNA and RNA are degraded into purine nucleotides and bases, which are then metabolized to xanthine and uric acid via the action of xanthine oxidase [61]. Uric acid does not undergo any further metabolism in humans and is excreted by the kidneys and into the intestinal tract. Elevated UA levels can be determined by several causes: increased production, decreased excretion, or genetic mutations associated with renal UA transportation [62,63]. Increased UA production is associated with purine-rich diets, characterized by high consumption of meat, bean seeds, mushrooms or some types of seafood [64]. Moreover, abnormal kidney function or competition for excretion with certain medications (e.g. diuretics) can alter the excretion of UA, thereby leading to increased UA level [65]. Further causes include high- 
fructose diets and excessive alcohol consumption. Namely, ethanol accelerates adenine nucleotide degradation by raising the plasma concentration of xanthine, which breaks down to produce UA. In addition, ethanol promotes dehydration by decreasing UA excretion [63]. Elevated UA levels in the blood can lead to hyperuricemia. This condition develops as a result of UA overproduction and/or altered UA secretion and is characterized by unusually high UA levels, higher that urate solubility [66]. The increase in consumption of fructosecontaining drinks, food, and table sugar during the last decades has contributed to hyperuricemia by increasing the conversion of ATP to inosine, a precursor in purine metabolism [67].

A noteworthy characteristic of serum UA is showing both, pro-oxidative and antioxidative effects. In case of acute rises, serum UA acts as an antioxidant at the intravascular level. Thanks to this property, serum UA plays the essential role of the major extracellular antioxidant of human blood [68], which can benefit the endothelial function. When serum UA levels are consistently high, serum UA acts as pro-oxidant at the intracellular level. As a result, lipid oxidation increases and the synthesis of nitric oxide, which has antiinflammatory and vasodilatory functions, decreases, potentially leading to cardiometabolic comorbidities [67,69]. The pivotal role of serum UA in the development of cardiometabolic abnormalities was also reported in other studies. For example, it was suggested that hyperuricemia may increase the risk of gouty arthritis and nephrolithiasis [70]. Therefore, it is of critical importance to understand the processes involved in augmenting serum UA levels, which might, in turn, play an active role in contributing to the development/progression of metabolic diseases.

\subsubsection{Serum UA and cardiometabolic risk factors}

The role of serum UA in the development of metabolic disorders has been investigated for many decades. Since the link among hyperuricemia, hyperglycemia and hypertension was first suggested by Kylin in 1923 [71], there has been a growing interest in the relationship between high serum UA levels and other metabolic abnormalities such as hyperglycemia, abdominal obesity, dyslipidemia, and hypertension [72,73]. A recent meta-analysis has demonstrated that high serum UA levels are associated with a modest increase in episodes of infarction and mortality [74]. Recent studies showed that serum UA is linked to cardiovascular dysfunction in pediatric obesity [75]. Furthermore, a recent investigation involving young individuals with hyperuricemia has suggested that a reduction in serum UA 
can lead to an increase of body weight and related CVD risk factors [76]. However, it is still not entirely clear whether the cardiovascular effects associated with high UA levels can be attributed only to UA - as an independent factor - or whether they are codetermined by the presence of other factors [67]. Many studies described correlations between elevated serum UA levels, MS and several of its components [62,77,78]. Two distinct mechanisms can explain the link between hyperuricemia and Two distinct mechanisms can explain the link between hyperuricemia and MS: the first mechanism is related to hyperuricemia - induced endothelial dysfunction leading to reduced insulin-stimulated nitric oxidative - induced vasodilation in skeletal muscle, and therefore to reduced glucose intake in skeletal muscle [79]. A bidirectional causal effect between hyperuricemia and hyperinsulinemia was suggested. The second mechanism is related to the fact that uric acid induces oxidative and inflammatory alterations in adipocytes, since xanthine oxidoreductase, responsible for generating UA from xanthine, which is expressed in adipocytes and is critical to the adipogenesis process [80]. Even if the connection between hyperuricemia and MS has not been totally understood yet, many studies have described correlations between serum UA levels, MS, and several of MS components in children and adolescents [81,82]. Indeed, Cardoso et al. [83] suggested an association between high levels of uric acid and MS in adolescents. For instance, every $1 \mathrm{~kg} / \mathrm{m}^{2}$ increment in BMI is associated with a $5.74 \mu \mathrm{mol} / \mathrm{L}$ increase of serum UA levels. These results were further supported by Jones et al. [84]. The Bogalusa Heart Study demonstrated that elevated serum UA levels play a pivotal role in the pathogenesis of MS already during adolescence, suggesting that serum UA may help the early identification of high risk individuals for MS [85].

\subsubsection{Serum UA and type 2 diabetes}

Elevated serum UA levels seem to be involved in the development of diabetes: high serum UA levels were found to be closely associated with insulin resistance and diabetes mellitus type 2 [86]. In particular, one-quarter of diabetes cases can be attributed to high serum UA levels. This outcome most likely reflects the biochemical interaction between plasma glucose and purine metabolism, which leads to increased excretions of serum UA during hyperglycemia and glycosuria [87]. In Germany, a population-based prospective study showed that serum UA was a strong risk factor for diabetes [88]. A recent study suggested that the increase in serum UA has a positive correlation with insulin resistance in obese children and adolescents. It was found that for every increase of $1 \mathrm{mg} / \mathrm{dL}$ in serum uric acid 
levels, there would be a $91 \%$ increase in the chance of insulin resistance [89]. It is worth mentioning that in prepubertal obese children, elevated levels of serum UA seem to be an early metabolic alteration associated with insulin resistance features [90]. Subsequent studies revealed that insulin resistance was very low in healthy obese individuals compared to unhealthy ones and that it increased significantly with the number of metabolic obesity comorbid disorders [41]. Low prevalence of insulin resistance was reported among obese individuals without significant comorbidities, suggesting that a preserved insulin sensitivity may be the key mechanism underlying healthy obesity [91].

\subsubsection{Serum UA and hypertension}

Numerous studies have demonstrated that hyperuricemia carries an increased risk for development of hypertension independently of other risk factors $[62,80]$. The strength of the relationship between serum UA level and hypertension decreases with increasing individual age and duration of hypertension, suggesting that serum UA levels may be more important in younger individuals with early-onset hypertension [84]. Several authors have emphasized that serum uric acid plays a role in pediatric hypertension. High serum UA levels were observed in about $90 \%$ of adolescents with recent onset hypertension and the serum UA level correlated with BP values [67]. Viazzi et al. [92] found that serum UA was directly related to hypertension independently of gender, puberty, BMI, HOMA-IR and renal function in children and adolescents. Various studies demonstrated that hypertension could lead to hyperuricemia. Hypertension can cause microvascular injury $[90,93,94]$ which then leads to a state of tissue hypoxia and to a consequent increase in lactate production, which in turn impair the renal clearance of urate. Furthermore, tissue hypoxia also induces the production of some precursors of uric acid, such as adenosine, hypoxanthine and xanthine oxidase [95]. In addition, recent studies report that hyperuricemia is involved in the reduction of nitric oxide release and in the activation of the renin-angiotensin system. Both mechanisms cause renal vasoconstriction and, therefore, lead to increased blood pressure [96]. Serum UA's role in hypertension and cardiometabolic risk is demonstrated by the increased production of hs-CRP in endothelial and smooth muscle cells when uric acid is present [97]. 


\subsubsection{Serum UA and kidney-related complications}

Moreover, increasing evidence suggests that high serum UA levels in obese individuals may cause kidney damage [98]. A recent study described that chronic kidney disease is related to serum UA levels, MS and obesity [99]. One possibility is that underlying mechanisms, such as endothelial dysfunction and oxidative stress, might c both kidney damage and the MS [100]. Some authors show that diets with high sugar addition, which implicates excess fructose, might have a key role in development of MS and kidney disease by elevating serum UA [101]. Krishnan et al. showed that the serum UA levels are linked to diabetic retinopathy in patients with type 2 diabetes mellitus [102]. Other studies reported that uric acid is involved in the reduction of nitric oxide in renal macula densa and in the direct stimulation of the renin-angiotensin system, leading to vasoconstriction and higher blood pressure $[103,104]$. In addition, cystatin C, albumin and UA were found to improve the identification of risk associated with chronic kidney diseases [105,106].

\subsubsection{Connection between Serum UA levels and metabolic health status}

Despite the evidence that serum UA is a cardiometabolic risk factor [107], it is rarely associated in the literature with the metabolic health status in the young population. Very few studies have addressed this association directly. One example is a recent study from Mangge et al. that examined the influence of serum uric acid in the development of metabolic abnormalities in overweight/obese young individuals. The authors performed a cross-sectional investigation analyzing a group of 299 overweight and obese children aged 8-18 from the STYJOBS/EDECTA cohort, allocated into three subgroups based on their weight and the presence of metabolic abnormalities: the normal weight control group, the MHO group and the MUO group. The results indicated elevated serum UA as the best predictor of unhealthy obesity in young population [37,41]. The emergence of serum UA as possible indicator to distinguish between metabolic healthy and unhealthy phenotype is believed to have relevant implications for obesity treatment and research in the pediatric population. More research would be necessary to consolidate the position of serum UA as a clinically relevant indicator of the obesity phenotype in youth, and, perhaps, even a risk modifying therapeutic target. 


\section{THE PROJECT RESEARCH}

\subsection{Research question and hypotheses}

As already stated in previous paragraphs, obesity is one of the most serious health issues faced by the current generation of children and adolescents and it should be prevented as early in life as possible. It is widely accepted that obese children are at high risk for developing metabolic complications that eventually may progress to type 2 diabetes and cardiovascular diseases [1]. Timely and carefully planned preventive measures are needed to reduce the risk of health-related consequences later in life. However, the concept of metabolically "healthy" obesity (MHO) was recently introduced into the field of pediatric obesity to describe obese children without any metabolic complications, in contrast to those with metabolically unhealthy obesity (MUO) [50]. Because of this, research has been focusing on potential clinical and metabolic indicators that may distinguish the MHO from MUO phenotypes and that can contribute to a better understanding of associated mechanisms. In this thesis, I focused on the distinction between MHO and MUO phenotypes and their relationship with serum uric acid in the pediatric population. Currently, there is a paucity of studies regarding these topics. Additionally, in this work I examine the possibility of using serum uric acid as an indicator of MUO phenotype in obese children and adolescents. Serum uric acid has been associated with risks of developing metabolic complications such as metabolic syndrome and type 2 diabetes mellitus in seemingly healthy obese individuals [108] and, therefore, is a promising health status biomarker for young individuals. More specifically, the following research questions are addressed:

1) What are the potential clinical and metabolic indicators that can be used to distinguish between MHO and MUO in children and adolescents?

2) Is the uric acid a potential indicator for the MUO phenotype in overweight or obese children and adolescents?

3) Is there a consistent association between serum uric acid and other cardiovascular risk factors among children and adolescents in Germany? 


\subsection{The LIFE-Child study}

The data used in the present study were obtained from the LIFE-Child study, which assessed individuals aged 0 to 18 years and is a part of the "Leipzig Research Center for Civilization Diseases (LIFE)", a major research project of the University of Leipzig.

The LIFE-Child study was designed in 2011 with the broad aim of understanding how and through which mechanisms metabolic and environmental factors influence growth, health and development processes in newborns, children and adolescents in Germany [109]. Since its inception, LIFE-Child studies have been a source of evidence for the health inequalities in children and adolescents in Leipzig, with recent contributions focusing on age-related health conditions. Through the data provided by the LIFE-Child study it is possible to investigate complex associations between life circumstances, behavior and health outcomes. Additionally, LIFE-Child provides reference data for health-related indicators.

The instruments used for data collection were a combination of interviews and questionnaires addressing socio-demographic characteristics, personal, family history, anthropometric and laboratory measurements. The participants were recruited by the health department, by practicing pediatricians, by inviting school classes and by public relations (website, social networking, flyers and events).

Ethical approval for the study was obtained from the ethics committee of the Medical Faculty of the University of Leipzig (file reference: Reg. Nr. 264-10-19042010). Parents or legal guardians of the participants gave written informed consent for their data to be used for bona fide research purposes of data. 
2 PUBLICATION MANUSCRIPT 
Serum uric acid levels as an indicator for metabolically unhealthy obesity in children and adolescents

Edrienny Patrícia Alves Accioly Rocha, Mandy Vogel, Juraj Stanik, Diana Pietzner, Anja Willenberg, Antje Körner, Wieland Kiess

Submitted in: Hormone Research in Pediatrics

Accepted for publication by July 2018 
Original Paper

Serum uric acid levels as an indicator for metabolically unhealthy obesity in children and adolescents

Edrienny Patrícia Alves Accioly Rocha ${ }^{\mathbf{1 2},}$, Mandy Vogel ${ }^{1,3}$, Juraj Stanik ${ }^{\mathbf{3}, 4}$, Diana Pietzner ${ }^{\mathbf{1 2},}$ Anja Willenberg ${ }^{6}$, Antje Körner ${ }^{5}$, Wieland Kiess ${ }^{1,2 *}$

Institute $\quad{ }^{1}$ University of Leipzig, LIFE-Child- Leipzig Research Center for Civilization Diseases, 04103 Leipzig, Germany

${ }^{2}$ University of Leipzig, Hospital for Children and Adolescents, 04103 Leipzig, Germany

${ }^{3}$ University of Leipzig, Centre of Paediatric Research (CPL), 04103 Leipzig, Germany ${ }^{4}$ Department of Pediatrics, Medical Faculty, Comenius University, and Institute of Experimental Endocrinology, Biomedical Research Center, Slovak Academy of Sciences, 83101 Bratislava, Slovakia

${ }^{5}$ Hospital for Children and Adolescents, Department of Women and Child Health, University Hospitals, University of Leipzig, Liebigstraße 20a, D04103 Leipzig, Germany

${ }^{6}$ University of Leipzig, Institute of Laboratory Medicine, Clinical Chemistry and Molecular Diagnostics (ILM), 04103 Leipzig, Germany

Running headline: Uric acid in metabolically unhealthy obesity children

*Address of correspondence:

Prof. Dr. med. Wieland Kiess

University of Leipzig, Hospital for Children and Adolescents

Liebigstraße 20a, 04103 Leipzig, Germany

Phone: 0049-341-9726000

Fax: 0049-341-9726009

Email: wieland.kiess@medizin.uni-leipzig.de 


\section{Keywords}

metabolically healthy obesity, metabolically unhealthy obesity, uric acid, children, obesity

\section{Abstract}

Background: Metabolically healthy obesity (MHO) refers to those individuals who do not show cardiometabolic abnormalities. Our aim was to identify potential clinical and metabolic indicators that may help to distinguish between metabolically healthy and unhealthy individuals amongst overweight and obese (ov/ob) children and adolescents. Methods: The study involved $246 \mathrm{ov} / \mathrm{ob}$ and 212 normal weight individuals enrolled in the LIFE-Child study, aged between 6 and 18 years. Overweight/obese individuals without cardiovascular risk factors (fasting serum lipids, blood pressure and glucose) were classified as MHO. Individuals meeting one or more criteria of cardiovascular risk factors were classified as metabolically unhealthy obesity (MUO). Results: Among the 246 ov/ob individuals, 173 (70\%) were MHO and 73 (30\%) were MUO. The MHO individuals were younger, more likely to be male and had lower BMI-SDS. In the logistic regression models, UA SDS (OR 1.61, 95\% CI 1.1 - 2.6, $p=.004$ ), waist circumference SDS (OR 2.50, 95\% CI 1.2 - 6.4, P=. 017), and C-peptide (OR 4.05, 95\% CI $3.5-91, p=.003$ ) were significant indicators of MUO. Conclusion: Our results suggest that nearly one-third of the ov/ob children are already identified as MUO. Serum levels of UA can be used as an indicator of unhealthy obesity in youth where lower levels of UA indicate a lower risk and higher levels suggest a higher risk of MUO. We note that the relevance of identifying potential indicators remains the first most important step in future clinical research. 


\section{Introduction}

Excessive body fat during childhood and adolescence instigates the first changes in the metabolism, vessels, and organs, which may lead to severe cardiometabolic complications, such as increased risk of cardiovascular dysfunction, hypertension, dyslipidemia and type 2 diabetes mellitus [1]. In fact, both overweight and obesity in children have increased by $47.1 \%$ since 1980 [2]. Its multifactorial nature complicates both therapy and prevention, rendering it a major problem and an important challenge for public health around the world [3]. Although the latest studies from several countries worldwide suggest a stabilization trend in the prevalence of obesity, especially among younger children, its prevalence in adolescents continues to increase [4]. Paradoxically, increasing evidence shows that a subgroup of overweight and obese individuals, reported as "metabolically healthy obesity", seems to be less prone to have the typical obesity-associated metabolic disorders, in contrast to those with metabolically unhealthy obesity [5]. The MHO has been identified by a set of favorable metabolic profiles, including preserved insulin sensitivity, the absence of criteria for metabolic syndrome, increased physical activity, low inflammatory indicators, hepatic fat content, and hormonal profile [6]. These factors might differentiate between metabolically healthy and metabolically unhealthy obese individuals. Although MHO in adult populations has been well-studied, research focused on children and adolescents is far more scarce [7]. The reported prevalence of MHO in children varies considerably, ranging from $6 \%$ to $75 \%$, depending on the classification system used to define this condition [8,9]. Due to a lack of consensus, the definition of MHO remains controversial [10]. Therefore, it is essential to investigate underlying mechanisms of the metabolically healthy and unhealthy phenotype in overweight and obese individuals [11]. Studies aimed at identifying new biomarkers that may distinguish the different phenotypes of obesity are required since such indicators could become relevant tools for identifying future diseases, making an accurate prognosis and planning intervention strategies [12].

Over the last years, it has been suggested that further biomarkers, such as serum uric acid (UA), are associated with risks of developing metabolic syndrome, type 2 diabetes mellitus and incident cardiovascular events [13]. In fact, uric acid has been reported to be a clinically important marker of inflammation linked to metabolic disorders in seemingly healthy obese individuals [14]. Currently, there is a paucity of recent data concerning the relation among biochemical variables with MHO and MUO in the pediatric population. On the basis of these observations, this study has endeavored 1) to identify potential clinical and metabolic indicators that may help to distinguish between metabolically healthy and metabolically 
unhealthy phenotypes; 2) to explore the relationship between serum uric acid levels and metabolic health in overweight and obese children and adolescents. In addition, we hypothesized that serum uric acid might be an indicator of the development of adverse cardio-metabolic outcomes in obese children and adolescents. 


\section{Methods}

\section{Research design and population}

The participants' data in the present study were collected from the ongoing "Leipzig Research Centre for Civilization Diseases (LIFE)" Child study of the University of Leipzig, which initiated in 2011. The instruments used for data collection were a combination of examinations and questionnaires addressing demographic issues, personal and family history, anthropometric, and laboratory measurements. Full details have been reported previously $[15,16]$. In 801 children and adolescents serum uric acid levels were available (LIFE Child cohort). After excluding those who were underweight (BMI-SDS $<-1.28$ ), had missing values on data required for defining metabolic health status, had any chronic diseases, such as diabetes mellitus type 1, diagnosis of liver disease, or were taking any medication that affects glucose or lipid metabolism, 458 individuals aged 6-18 years remained (Figure 1) for analysis (239 male and 219 female). Among these, 45.2\% $(\mathrm{n}=207)$ were obese (BMI-SDS $\geq 1.88)$ and $8.5 \%(n=39)$ were overweight (BMI-SDS between 1.28 and 1.88) and they were evaluated alongside with $46.3 \%(\mathrm{n}=212)$ normal weight control group (BMI-SDS between -1.28 and 1.28) [17]. Due to the fact that few participants were overweight, we combined overweight and obese for the analyses. This study was approved by the Ethical Committee of the University of Leipzig under registration No. 264-1019042010. Written informed consent was obtained from parents or legal guardians of the participants before the children and adolescents were included in the study.

\section{Anthropometric and clinical measurements}

Anthropometric and laboratory data were collected by trained health investigators using standardized procedures. Body mass index (BMI) was calculated by weight in kilograms $(\mathrm{kg})$ divided by the square height in meters $(\mathrm{m})\left(\mathrm{kg} / \mathrm{m}^{2}\right)$. Age- and sex-specific BMI standard deviation scores (BMI-SDS) were calculated using the German reference data [17] as recommended by the German Working for Pediatric Obesity Consensus Guideline [18]. Waist circumference (WC), defined as midpoint between lowest rib and the upper anterior iliac spine, was measured using an inelastic tape in centimeters (cm). WC-SDS was calculated based on German references [19]. Waist-to-height ratio (WtHr) was calculated as waist circumference $(\mathrm{cm})$ divided by height $(\mathrm{cm})$. Pubertal development was assessed according to the definition of the Tanner stage of breast development in girls and genital stage in boys. Pubertal development was divided into three pubertal stages (Tanner stage I was classified as prepubertal; Tanner stage II, III and IV as pubertal; Tanner stage V as post pubertal) [20]. Blood pressure (BP) was measured at the right arm after a 10-minute resting 
period in the supine position. BP was measured three times with a one-minute interval, and the average of all measurements was used for analyses [21]. Participants also completed questionnaires related to their demographic characteristics, medical history, alcohol consumption, and dietary habits.

\section{Biochemical parameters}

Fasting venous blood samples were collected from individuals at LIFE Child study. The measurement of laboratory parameters was performed at the Institute of Laboratory Medicine, Clinical Chemistry and Molecular Diagnostics (ILM), University Hospital Leipzig. Total cholesterol, triglyceride, HDL-cholesterol, AST, ALT (UV tests), GGT, LDLcholesterol, UA, alkaline phosphatase (colorimetric tests) as well as high sensitive C-reactive protein (latex-enhanced immunoturbidimetric test) were analyzed in serum samples with reagent from Roche Diagnostics using Cobas 8000 System according to the manufacturer protocol (Roche Diagnostics GmbH, Mannheim, Germany). Serum cystatin C (CysC) was analyzed using the turbidimetric immunoassay (PETIA) Tina-quant ${ }^{\circledR}$ Cystatin $C$ (Roche Diagnostics). An oral glucose tolerance test was performed in all individuals according to the established recommendations [22]. oGTT derived laboratory data (insulin and glucose concentrations) were drawn at baseline and after 15, 30, 60, 90, $120 \mathrm{~min}$. Insulin measurement was performed using the fully automated immunoassay systems of Liaison (Diasorin, Dietzenbach, Germany) and Cobas ECLIA-test on Cobas 8000 e602 (Roche, Mannheim, Germany). Both assays were adjusted for the 1.IRP WHO reference standard. Intra-assay and inter-assay coefficients were below 5.7\% [23]. Insulin sensitivity we examined by the homeostasis model assessment index (HOMA-IR) [24], which was calculated using the following formula: HOMA-IR $=($ Insulin $[\mathrm{mU} / 1] \times \mathrm{Glucose}[\mathrm{mmol} / \mathrm{l}]) / 22.5$. The whole-body insulin sensitivity index (WBISI), was determined using glucose and insulin values during an oral glucose-tolerance test (OGTT) applying the Matsuda calculation [25]. 


\section{Defining metabolic healthy status}

For the purpose of defining metabolic status, the overweight/obese children and adolescents have been divided into two groups (i.e. metabolically healthy or metabolically unhealthy status) according to the following criteria (Supplemental Table 1): Individuals with the presence of at least one of the following cardiovascular risk factors have been classified as having MUO: dyslipidemia, defined as i) serum triglycerides (TG) > 95th percentile or ii) serum HDL cholesterol (HDL-C) $<5$ th percentile according to the American Academy of Pediatrics [26]; Hypertension, defined as iii) blood pressure > 95th percentile for height, sex, and age [27]; Impaired fasting glucose (IFG), defined as iv) fasting serum glucose $\geq 5.6$ mmol/l. On the contrary, MHO status was based on the absence of hypertension, dyslipidemia, and IFG following the definition of Prince et al [8]. The parameters used to define metabolic healthy status were standardized because of age dependence. In addition we used the 95th percentile as the cut-off for the aforementioned cardiovascular risk factors.

\section{Statistical analysis}

Gaussian distribution of all variables was checked using the Shapiro-Wilk test in addition to graphical methods. All data are reported as mean \pm standard deviation (if normally distributed), and median and interquartile range (if non-normally distributed). Categorical data are presented as number (n) and percentage (\%). Differences among groups were tested using chi-squared test $\left(x^{2}\right)$ for categorical variables and Mann-Whitney-Wilcoxon test or ttest for continuous variables, when appropriate, with a 95\% confidence interval $(95 \% \mathrm{CI})$ and the risk difference (RD) between the MHO and MUO groups. We used hierarchical linear regression analysis to evaluate the strength of the relationship between serum UA concentrations and cardiovascular risk factors. All statistical models were adjusted for age and sex. For overweight/obese individuals, logistic regression analysis was performed to assess the association between clinical and metabolic variables as independent variables and metabolic unhealthy status as dependent variable, controlled for age, sex, pubertal stage and BMI-SDS. Furthermore, logistic regression analyses were performed including gender, age, pubertal stage, waist circumference, UA, C-peptide, hs-CRP, and albumin in order to identify significant indicators of MUO. The regression coefficients are presented as odds ratios (ORs) with 95\% confidence intervals (CI). In addition, all analyses were performed both including and excluding the overweight category; since our analyses generated similar results, all children with (BMI-SDS $\geq 1.28$ ) were included in the final analyses. In order to remove the age dependence, we standardized some parameters such as fasting serum 
glucose, HDL-c, triglycerides, as well as UA levels using a LMS-type method (LMSP) implemented in the package gamlss [28]. The age- and sex- specific percentiles were found preferable, especially in young children. All results with a $p$ value less than 0.05 were considered to be statistically significant. Data analysis was performed using the statistical software R (version 3.1.2, R core team, Vienna, Austria) [29]. 


\section{Results}

Anthropometric and metabolic characteristics of the study population are displayed in table 1. The presented data consists of 246 overweight/obese and 212 normal weight children and adolescents (mean age $11.1 \pm 2.8$ years, $52 \%$ male). The mean BMI-SDS was $-0.04 \pm 0.68$ in normal weight and $2.32 \pm 0.52$ in overweight/obese children. $41 \%$ of them were classified as prepubertal, $47 \%$ were pubertal and $12 \%$ were postpubertal. Based on the cardiovascular risk factors, the overweight/obese individuals were classified into two groups; 173 (38.0\% of the total study sample) "metabolically healthy obesity" (MHO, no criteria of cardiovascular risk factors) and $73(16.0 \%)$ "metabolically unhealthy obesity" (MUO, presence of one or more criteria of cardiometabolic risk factors). These two groups were compared to the control group (normal weight individuals, 212 [46.0\%]). Among the cardiovascular risk factors in the MUO individuals, hypertriglyceridemia was the most frequent (in $54.2 \%$ of the individuals), followed by low serum HDL-C (45.8\%), hypertension (19.5\%) and IFG (14.7\%). The MHO individuals were more often prepubertal than MUO individuals. As expected MUO group had significantly higher median BMI-SDS when compared to the MHO group (table 1). Circulating concentrations of uric acid SDS, C-peptide and hs-CRP were significantly higher in MUO compared to MHO group. Additionally, cystatin C levels were significantly higher in the controls compared to the MHO and MUO, whereas no significant difference was found between MHO and MUO groups. Markers of liver function, including ALT, AST and alkaline phosphatase, were similarly increased in MHO and MAO groups, exhibiting no differences between them, with the exception of GGT levels, which were significantly higher in MUO as compared to the MHO group. The used parameters defining the metabolic health status are summarized in table 2. MUO showed significantly higher triglycerides SDS, glucose SDS, systolic and diastolic blood pressure SDS compared to MHO individuals. As expected, glucose metabolism was altered in MUO as indicated by increased insulin levels and reduced WBISI with normal glycaemia compared to the MHO group. Anthropometric and biochemical characteristics of all participants of the study are presented in Supplemental Table 2. MUO children showed significantly increased LDL cholesterol paired with reduced HDL cholesterol SDS when compared to MHO children. Hematological indicators, including hemoglobin, red blood cell, platelet, white blood cell was increased in the MUO compared to the MHO group, although no significant differences were found between both groups. Levels of testosterone and SHBG were higher in the MHO in comparison to the MUO group; whereas levels of estradiol were significantly lower in the MHO than in the MUO group. However, after stratifying the analyses by Tanner stage to 
avoid a bias caused by the different age distributions of MHO and MUO, the difference pertains only significant for Tanner 1 stage where the MHO group shows significantly lower values of estradiol. The results of the hierarchical regression analyses were incorporated to examine further the relationship between serum UA and the parameters used to define the metabolic health status. They are summarized in Table 3. Uric acid serum concentrations were associated with serum triglyceride SDS, systolic blood pressure, CysC and C-peptide. Furthermore, UA SDS was negatively associated with serum HDL SDS. However, we did not find a significant effect of glucose-SDS on UA serum levels. Additionally, a logistic regression analysis was performed to identify indicators of MUO phenotype as shown in table 4. Based on the relevant clinical and metabolic variables shown in table 1, the set of independent variables like waist circumference, UA, C-peptide, albumin and hs-CRP were included in the logistic regression models. Variables used for defining the MUO were not included in the logistic regression analysis. In conclusion, higher levels of C-peptide, waist circumference SDS, UA SDS and pubertal stage were identified as significant indicators of the MUO phenotype. However, no significant effect of sex was found. Higher levels of hsCRP and albumin were non-significant MUO indicators when controlled for age, gender, pubertal stage and BMI-SDS (table 4). 


\section{Discussion}

This study was designed to identify potential clinical and metabolic indicators that may distinguish between metabolically healthy and metabolically unhealthy phenotypes in overweight and obese children and adolescents. The results associating serum uric acid levels with the MUO status in youth are of particular interest, considering that such data were scarcely available up to now. Our study yielded several important findings:

(i) Regarding cardiometabolic characteristics, the MHO children were identified to be younger and less overweight in terms of BMI-SDS and to have lower waist circumference, lower insulin resistance index (HOMA), better insulin sensitivity and lower levels of proinflammatory markers. Such results which are supported by other studies [30,31], may place that a subset of overweight/obese children was at relatively low cardiometabolic risk despite possessing a high amount of body fat [32]. Interestingly, concerning the liver profile, the concentrations of ALT and AST were not significantly different between the MHO and MUO children. In contrast to our results, it has been reported that ALT and AST serum concentrations have been significantly different between MHO and MUO [33]. These findings could also be attributed to a healthier constitution, younger age, effects of the ethnicity or smaller sample size of studied participants. However, a study from Canada found a significant difference in the levels of GGT in MHO compared to the MUO group [34], as in the present work.

(ii) Another point of interest is that there were higher proportions of MHO (38.5\%) in ov/ob children and adolescents than described by other authors who evaluated obesity in the pediatric age [35,36]. For instance, a recent study examining Chinese children and adolescents aged 6- to 18-years found that prevalence rates were $3.9 \%$ and $36.7 \%$ using two different MHO criteria defined respectively by insulin resistance and cardiometabolic parameters [37]. Using the same MHO criteria as in the present study, a recently published German study on the effect of pubertal status revealed that a large proportion of obese children (49.3\%) exhibited a MHO status [38]. It is likely that the high variability in reported MHO prevalences could be explained by the lack of a standard definition of MHO, specific cut-off values, small sample sizes, different age ranges, as well as behavioral differences between populations [39-41].

(iii) A comprehensive logistic regression model identified C-peptide, waist circumference SDS, UA SDS, and pubertal stage as indicators of the MUO status. The current study demonstrated significantly higher levels of C-peptide and insulin in the MUO group, when compared to MHO, indicating an increased $\beta$-cell load. This result might indicate early 
changes in the glucose metabolism of obese children which could be associated with the reduction of insulin sensitivity, as implied by the increased HOMA-IR and the reduced WBISI. Previously published results have shown C-peptide to be associated with insulin resistance, cardiometabolic abnormalities belonging to the metabolic syndrome, dyslipidemia, hypertension hyperuricemia and type 2 diabetes mellitus in both obese children and adults $[42,43]$. Cardellini et al [44] demonstrated an important role of C-peptide levels in the chemotactic effect on the inflammatory cells and suggested that it promotes the onset of atherosclerosis. To best of our knowledge, this is the first study addressing Cpeptide as potential indicator of MUO in ov/ob children and adolescents. In our study, uric acid was found to be a significant indicator of MUO status after adjusting for age, sex, pubertal status and BMI-SDS. This finding is in agreement with those recently obtained by two Austrian authors, who examined overweight/obese children and adolescents and have shown that higher serum UA levels were a significant predictor of metabolically unhealthy in young populations $[36,45]$. In youth, serum UA increases progressively from an early age with body growth and a plateau around 15 to 17 years [46]. In our study, concentrations in overweight/obese children are significantly higher than in their normal weight peers. This may be of particular significance for overweight/obese individuals who may exhibit chronic long-term hyperuricemia. In fact, increased UA levels may contribute to endothelial dysfunction by instigating antiproliferative effects on endothelium and impairing nitric oxide production, therefore, it has been associated with the risk of cardiovascular disease [47]. In this study we found that UA was strongly associated with blood pressure. A biological explanation for this result is supported by animal models, which showed that after the onset of hyperuricemia, hypertension occurs. This indicates that the reduction of nitric oxide in the renal macula and the direct stimulation of the renin-angiotensin system are probably the mechanisms to cause vasoconstriction and, therefore, increase blood pressure [48]. According to our findings, the MUO is characterized by higher albumin and CysC levels as compared to the MHO children. In addition, CysC, albumin and UA were found to be sensitive in the identification of mild reductions in kidney function, and could potentially identify young individuals at high risk for the future development of cardiometabolic diseases [49,50]. These facts highlight that the association among UA levels and cardiometabolic disorders might be a relevant area of research, recognizing the implications of the discovery of potential new indicators and therapeutic targets in individuals with a metabolically unhealthy phenotype.

Furthermore, in our study, the pubertal children had a higher odds of being of MUO 
phenotype. Reinehr et al [38] showed that entering puberty doubles the risk of switching from MHO to MUO. The difference between pubertal stage and cardiometabolic alterations may be attributable to the physiological changes of body composition and the influence of sex hormones during puberty development [51].

The major strength of this study is the description of a comprehensive clinical and metabolic analysis of MHO and MUO children and adolescents. However, despite our innovative findings, our study has the following limitations: First, the cross-sectional design of the study could not reveal any causal relationships between the metabolic health status and the investigated indicators. Further assessment of the influence of cardiovascular risk factors when obese children enter puberty is necessary. Second, it is essential to reproduce this study in a longitudinal research among different young populations. Furthermore, our study had a limited sample size, and therefore our observations need to be confirmed in a bigger cohort. Lastly, there is no standard definition of MHO. In conclusion, our study is one of the few to suggest that high uric acid levels increase the likelihood of MUO. Future longitudinal studies in larger populations are required to confirm that uric acid is an indicator of metabolic phenotypes associated with obesity, and that it may represent a useful indicator to identify children with increased cardiometabolic risk. 


\section{Financial support:}

The project was supported by the LIFE-Child Research Center for Civilization Diseases funded by the European Union through the European Regional Development Fund (ERDF), the Free State of Saxony and by grant from the Coordination of Improvement of Higher Level Personnel (CAPES) from Brazil. J.S. is supported by ESPE (European Society for Pediatric Endocrinology) Research Fellowship.

\section{Competing interests}

The authors state that there is no conflicts of interest. 


\section{REFERENCES}

1. Bussler S, Penke M, Flemming G, Elhassan YS, Kratzsch J, Sergeyev E, et al. Novel Insights in the Metabolic Syndrome in Childhood and Adolescence. Horm Res Paediatr. 2017;88(3-4):181-93. doi: 10.1159/000479510. PubMed PMID: 28848168.

2. Marie $\mathrm{Ng} \mathrm{PhD,} \mathrm{Tom} \mathrm{Fleming} \mathrm{BS,} \mathrm{Margaret} \mathrm{Robinson} \mathrm{BA,} \mathrm{Blake} \mathrm{Thomson} \mathrm{BA,}$ Nicholas Graetz BS, Christopher Margono BS, et al. Global, regional, and national prevalence of overweight and obesity in children and adults during 1980-2013: a systematic analysis for the Global Burden of Disease Study 2013. The Lancet. 2014;384:766-81.

3. Ogden CL, Carroll MD, Kit BK, Flegal KM. Prevalence of obesity and trends in body mass index among US children and adolescents, 1999-2010. JAMA. 2012;307(5):48390. doi: 10.1001/jama.2012.40. PubMed PMID: 22253364.

4. Kiess W, Penke M, Sergeyev E, Neef M, Adler M, Gausche R, et al. Childhood obesity at the crossroads. J Pediatr Endocrinol Metab. 2015;28(5-6):481-4. doi: 10.1515/jpem2015-0168. PubMed PMID: 25928753.

5. Blüher M. The distinction of metabolically 'healthy' from 'unhealthy' obese individuals. Curr Opin Lipidol. 2010;21(1):38-43. doi: 10.1097/MOL.0b013e3283346ccc. PubMed PMID: 19915462.

6. Blüher M. Are metabolically healthy obese individuals really healthy? Eur J Endocrinol. 2014;171(6):R209-19. doi: 10.1530/EJE-14-0540. PubMed PMID: 25012199.

7. Blüher S, Schwarz P. Metabolically healthy obesity from childhood to adulthood - Does weight status alone matter? Metabolism. 2014;63(9):1084-92. doi: 10.1016/j.metabol.2014.06.009. PubMed PMID: 25038727.

8. Prince RL, Kuk JL, Ambler KA, Dhaliwal J, Ball GDC. Predictors of metabolically healthy obesity in children. Diabetes Care. 2014;37(5):1462-8. doi: 10.2337/dc13-1697. PubMed PMID: 24574347.

9. Rey-Lopez JP, Rezende LF de, Pastor-Valero M, Tess BH. The prevalence of metabolically healthy obesity: a systematic review and critical evaluation of the definitions used. Obes Rev. 2014;15(10):781-90. doi: 10.1111/obr.12198. PubMed PMID: 25040597.

10. van Wijk DF, Boekholdt SM, Arsenault BJ, Ahmadi-Abhari S, Wareham NJ, Stroes ESG, et al. C-Reactive Protein Identifies Low-Risk Metabolically Healthy Obese Persons: The European Prospective Investigation of Cancer-Norfolk Prospective Population Study. J Am Heart Assoc. 2016;5(6). doi: 10.1161/JAHA.115.002823. 
PubMed PMID: 27260511.

11. Diniz, Maria de Fatima Haueisen Sander, Beleigoli AMR, Ribeiro ALP, Vidigal PG, Bensenor IM, Lotufo PA, et al. Factors associated with metabolically healthy status in obesity, overweight, and normal weight at baseline of ELSA-Brasil. Medicine (Baltimore). 2016;95(27):e4010. doi: 10.1097/MD.0000000000004010. PubMed PMID: 27755484.

12. Gao B, Zhang L, Zhao M. Underweight but metabolically abnormal phenotype: Metabolic features and its association with cardiovascular disease. Eur J Intern Med. 2016;29:46-51. doi: 10.1016/j.ejim.2015.11.020. PubMed PMID: 26703431.

13. Karelis AD, Faraj M, Bastard J-P, St-Pierre DH, Brochu M, Prud'homme D, et al. The metabolically healthy but obese individual presents a favorable inflammation profile. $\mathbf{J}$ Clin Endocrinol Metab. 2005;90(7):4145-50. doi: 10.1210/jc.2005-0482. PubMed PMID: 15855252.

14. Liu Z, Que S, Zhou L, Zheng S. Dose-response Relationship of Serum Uric Acid with Metabolic Syndrome and Non-alcoholic Fatty Liver Disease Incidence: A Meta-analysis of Prospective Studies. Sci Rep. 2015;5:14325. doi: 10.1038/srep14325. PubMed PMID: 26395162.

15. Quante M, Hesse M, Dohnert M, Fuchs M, Hirsch C, Sergeyev E, et al. The LIFE child study: a life course approach to disease and health. BMC Public Health. 2012;12:1021. doi: 10.1186/1471-2458-12-1021. PubMed PMID: 23181778.

16. Poulain T, Baber R, Vogel M, Pietzner D, Kirsten T, Jurkutat A, et al. The LIFE Child study: A population-based perinatal and pediatric cohort in Germany. Eur J Epidemiol. 2017;32(2):145-58. doi: 10.1007/s10654-016-0216-9. PubMed PMID: 28144813.

17. Kromeyer-Hauschild K, Wabitsch M, Kunze D, Geller F, Geiß HC. Microsoft Word 481_Pseudo-Postprint_mit Abb.doc: Perzentile für den Body-mass-Index für das Kindes- und Jugendalter unter Heranziehung verschiedener deutscher Stichproben. Monatsschr Kinderhekd. 2001;149:807-18.

18. Reinehr T, Holl RW, Wabitsch M. The German Working Group of Obesity in Childhood and Adolescence (AGA): Improving the quality of care for overweight and obese children in Germany. Obes Facts. 2008;1(1):26-32. doi: 10.1159/000113405. PubMed PMID: 20054159.

19. Dathan-Stumpf A, Vogel M, Hiemisch A, Thiery J, Burkhardt R, Kratzsch J, et al. Pediatric reference data of serum lipids and prevalence of dyslipidemia: Results from a population-based cohort in Germany. Clin Biochem. 2016;49(10-11):740-9. 
doi: 10.1016/j.clinbiochem.2016.02.010. PubMed PMID: 26948098.

20. Tanner JM, Whitehouse RH. Clinical longitudinal standards for height, weight, height velocity, weight velocity, and stages of puberty. Archives of Disease in Childhood. 1976;51(3):170-9. doi: 10.1136/adc.51.3.170.

21. Neuhauser H, Thamm M. Blutdruckmessung im Kinder- und Jugendgesundheitssurvey (KiGGS). Methodik und erste Ergebnisse. Bundesgesundheitsblatt Gesundheitsforschung Gesundheitsschutz. 2007;50(5-6):728-35. doi: 10.1007/s00103007-0234-6. PubMed PMID: 17514457.

22. World Health Organisation. Definition and diagnosis of diabetes mellitus and intermediate hyperglycaemia. 2013.

23. Junge J, Engel C, Vogel M, Naumann S, Löffler M, Thiery J, et al. Neck circumference is similarly predicting for impairment of glucose tolerance as classic anthropometric parameters among healthy and obese children and adolescents. J Pediatr Endocrinol Metab. 2017;30(6):643-50. doi: 10.1515/jpem-2017-0079. PubMed PMID: 28489559.

24. Matthews DR, Hosker JP, Rudenski AS, Naylor BA. Homeostasis model assessment: insulin resistance and fl-cell function from fasting plasma glucose and insulin concentrations in man. Diabetologia. 1985;28(Suppl 7):412-9.

25. Matsuda M, DeFronzo RA. Insulin sensitivity indices obtained from oral glucose tolerance testing: Comparison with the euglycemic insulin clamp. Diabetes Care. 1999;22(9):1462-70. doi: 10.2337/diacare.22.9.1462.

26. Daniels SR, Greer FR. Lipid screening and cardiovascular health in childhood. Pediatrics. 2008;122(1):198-208. doi: 10.1542/peds.2008-1349. PubMed PMID: 18596007.

27. Miersch A, Vogel M, Gausche R, Siekmeyer W, Pfäffle R, Dittrich K, et al. Blood pressure tracking in children and adolescents. Pediatr Nephrol. 2013;28(12):2351-9. doi: 10.1007/s00467-013-2596-3. PubMed PMID: 23959541.

28. Rigby RA SD. Generalized additive models for location, scale and shape. J R Stat Soc C. $2005 ; 54(3): 507-54$.

29. Core Team (2014) R: A language and environment for statistical computing. R Foundation for Statistical Computing, Vienna, Austria [cited 2017 Jun 29]. Available from: URL http://www.R-project.org/.

30. Vukovic R, Milenkovic T, Mitrovic K, Todorovic S, Plavsic L, Vukovic A, et al. Preserved insulin sensitivity predicts metabolically healthy obese phenotype in children and adolescents. Eur J Pediatr. 2015;174(12):1649-55. doi: 10.1007/s00431-015-2587- 


\section{PubMed PMID: 26141171.}

31. Chun S, Lee S, Son H-J, Noh H-M, Oh H-Y, Jang HB, et al. Clinical Characteristics and Metabolic Health Status of Obese Korean Children and Adolescents. Korean J Fam Med. 2015;36(5):233-8. doi: 10.4082/kjfm.2015.36.5.233. PubMed PMID: 26435814.

32. Smith KJ, Bessell E, Magnussen CG, Dwyer T, Venn AJ. Does youth adiposity, or change in adiposity from youth to adulthood, predict metabolically healthy obesity in adulthood? Pediatr Obes. 2016;11(5):349-53. doi: 10.1111/ijpo.12065. PubMed PMID: 26317846.

33. Hong HC, Lee J-S, Choi HY, Yang SJ, Yoo HJ, Seo JA, et al. Liver enzymes and vitamin D levels in metabolically healthy but obese individuals: Korean National Health and Nutrition Examination Survey. Metabolism. 2013;62(9):1305-12. doi: 10.1016/j.metabol.2013.04.002. PubMed PMID: 23643404.

34. Messier V, Karelis AD, Robillard M-E, Bellefeuille P, Brochu M, Lavoie J-M, et al. Metabolically healthy but obese individuals: Relationship with hepatic enzymes. Metabolism. 2010;59(1):20-4. doi: 10.1016/j.metabol.2009.06.020. PubMed PMID: 19709695.

35. Khokhar A, Chin V, Perez-Colon S, Farook T, Bansal S, Kochummen E, et al. Differences between Metabolically Healthy vs Unhealthy Obese Children and Adolescents. Journal of the National Medical Association. 2017. doi: 10.1016/j.jnma.2017.02.008.

36. Weghuber D, Zelzer S, Stelzer I, Paulmichl K, Kammerhofer D, Schnedl W, et al. High risk vs. "metabolically healthy" phenotype in juvenile obesity - neck subcutaneous adipose tissue and serum uric acid are clinically relevant. Exp Clin Endocrinol Diabetes. 2013;121(7):384-90. doi: 10.1055/s-0033-1341440. PubMed PMID: 23519645.

37. Ding WQ, Yan YK, Zhang MX, Cheng H, Zhao XY, Hou DQ, et al. Hypertension outcomes in metabolically unhealthy normal-weight and metabolically healthy obese children and adolescents. J Hum Hypertens. 2015;29(9):548-54. doi: 10.1038/jhh.2014.124. PubMed PMID: 25652533.

38. Reinehr T, Wolters B, Knop C, Lass N, Holl RW. Strong effect of pubertal status on metabolic health in obese children: a longitudinal study. J Clin Endocrinol Metab. 2015;100(1):301-8. doi: 10.1210/jc.2014-2674. PubMed PMID: 25243573.

39. Gomez-Ambrosi J, Catalan V, Rodriguez A, Andrada P, Ramirez B, Ibanez P, et al. Increased cardiometabolic risk factors and inflammation in adipose tissue in obese subjects classified as metabolically healthy. Diabetes Care. 2014;37(10):2813-21. 
doi: 10.2337/dc14-0937. PubMed PMID: 25011950.

40. Ahl S, Guenther M, Zhao S, James R, Marks J, Szabo A, et al. Adiponectin Levels Differentiate Metabolically Healthy vs Unhealthy Among Obese and Nonobese White Individuals. J Clin Endocrinol Metab. 2015;100(11):4172-80. doi: 10.1210/jc.20152765. PubMed PMID: 26401592.

41. Elmaogullari S, Demirel F, Hatipoglu N. Risk factors that affect metabolic health status in obese children. J Pediatr Endocrinol Metab. 2017;30(1):49-55. doi: 10.1515/jpem2016-0128. PubMed PMID: 27992361.

42. Abdullah A, Hasan H, Raigangar V, Bani-Issa W. C-Peptide versus insulin: relationships with risk biomarkers of cardiovascular disease in metabolic syndrome in young arab females. Int J Endocrinol. 2012;2012:420792. doi: 10.1155/2012/420792. PubMed PMID: 22899917.

43. Ciresi A, Cicciò F, Radellini S, Giordano C. Utility of C-peptide for a reliable estimate of insulin secretion in children with growth hormone deficiency. Growth Horm IGF Res. 2016;29:71-7. doi: 10.1016/j.ghir.2016.05.001. PubMed PMID: 27235725.

44. Cardellini M, Farcomeni A, Ballanti M, Morelli M, Davato F, Cardolini I, et al. Cpeptide: A predictor of cardiovascular mortality in subjects with established atherosclerotic disease. Diab Vasc Dis Res. 2017:1479164117710446. doi: 10.1177/1479164117710446. PubMed PMID: 28565926.

45. Mangge H, Zelzer S, Puerstner P, Schnedl WJ, Reeves G, Postolache TT, et al. Uric acid best predicts metabolically unhealthy obesity with increased cardiovascular risk in youth and adults. Obesity (Silver Spring). 2013;21(1):E71-7. doi: 10.1002/oby.20061. PubMed PMID: 23401248.

46. Harlan WR, Cornoni-Huntley J, Leaverton PE. Physiologic determinants of serum urate levels in adolescence. Pediatrics. 1979(63):569-75.

47. Gustafsson D, Unwin R. The pathophysiology of hyperuricaemia and its possible relationship to cardiovascular disease, morbidity and mortality. BMC Nephrol. 2013;14:164. doi: 10.1186/1471-2369-14-164. PubMed PMID: 23895142.

48. Choi HK, Ford ES. Prevalence of the metabolic syndrome in individuals with hyperuricemia. Am J Med. 2007;120(5):442-7. doi: 10.1016/j.amjmed.2006.06.040. PubMed PMID: 17466656.

49. Harada M, Izawa A, Hidaka H, Nakanishi K, Terasawa F, Motoki H, et al. Importance of cystatin $\mathrm{C}$ and uric acid levels in the association of cardiometabolic risk factors in Japanese junior high school students. J Cardiol. 2017;69(1):222-7. 
doi: 10.1016/j.jjcc.2016.03.013. PubMed PMID: 27138369.

50. Hayashino Y, Okamura S, Tsujii S, Ishii H. Association of serum uric acid levels with the risk of development or progression of albuminuria among Japanese patients with type 2 diabetes: a prospective cohort study Diabetes Distress and Care Registry at Tenri (DDCRT 10). Acta Diabetol. 2016;53(4):599-607. doi: 10.1007/s00592-015-0825-x. PubMed PMID: 26935413.

51. Kiess W, Hoppmann J, Gesing J, Penke M, Korner A, Kratzsch J, et al. Puberty - genes, environment and clinical issues. J Pediatr Endocrinol Metab. 2016;29(11):1229-31. doi: 10.1515/jpem-2016-0394. PubMed PMID: 27771625. 
Tables

Table 1. Anthropometric and metabolic characteristics of normal weight controls, MHO and MUO children

\begin{tabular}{|c|c|c|c|c|c|c|}
\hline & $\begin{array}{l}\text { Normal weight } \\
\text { controls }\end{array}$ & МHO & MUO & RD $(95 \%$ CI $)$ & $\begin{array}{c}P \\
\text { value }\end{array}$ & $P$ value $^{b}$ \\
\hline $\mathrm{n}(\%)$ & $212(46)$ & $173(38)$ & $73(16)$ & & & \\
\hline \multicolumn{7}{|c|}{ Baseline characteristics, anthropometry } \\
\hline Age, years & $11.1 \pm 2.98$ & $11.2 \pm 2.64$ & $11.4 \pm 2.84$ & $0.20(0.03-0.98)$ & .610 & .785 \\
\hline Male sex, n (\%) & $109(51)$ & $96(55)$ & $34(49)$ & & .496 & .496 \\
\hline Pubertal status, $(\%)$ & & & & & .048 & .048 \\
\hline Prepubertal & 45.9 & 35.1 & 34.1 & & & \\
\hline Pubertal & 44.8 & 47.3 & 52.2 & & & \\
\hline Postpubertal & 9.3 & 17.6 & 13.7 & & & \\
\hline BMI, SDS & $-0.04 \pm 0.68$ & $2.32 \pm 0.52$ & $2.57 \pm 0.57$ & $0.25(0.09-0.38)$ & $<.001$ & .001 \\
\hline Waist circumference, SDS & $-0.2 \pm 0.69$ & $1.62(1.33-1.89)$ & $1.83(1.54-2.04)$ & $0.39(0.05-0.27)$ & $<.001$ & .000 \\
\hline \multicolumn{7}{|l|}{ Metabolic characteristics } \\
\hline HOMA-IR & $1.44(1.00-1.91)$ & $3.05(2.50-3.67)$ & $3.66(2.61-4.70)$ & $0.61(1.01-2.23)$ & $<.001$ & $<.001$ \\
\hline WBISI & $5.31(3.79-7.51)$ & $4.31(1.98-3.71)$ & $2.00(1.40-2.47)$ & $0.94(0.57-1.50)$ & $<.001$ & $<.001$ \\
\hline C-peptide, nmol/L & $0.58(0.42-0.69)$ & $0.79(0.64-0.97)$ & $0.97(0.73-1.19)$ & $0.18(0.08-0.25)$ & $<.001$ & $<.001$ \\
\hline Uric acid, SDS & $-0.49 \pm 0.85$ & $0.33(0.01-0.81)$ & $0.69(0.21-1.39)$ & $0.36(0.16-0.67)$ & $<.001$ & $<.001$ \\
\hline AST, U/L & $30.5(24.7-34.8)$ & $27.4(22.9-34.4)$ & $30.8(23.2-35.3)$ & $3.40(1-20-3.61)$ & .172 & .411 \\
\hline $\mathrm{ALT}, \mathrm{U} / \mathrm{L}$ & $17.4(14.5-21.7)$ & $18.1(14.5-21.7)$ & $18.7(15.5-23.4)$ & $0.60(0.21-0.84)$ & .209 & .187 \\
\hline GGT, U/L & $12.1(10.3-13.9)$ & $12.8(10.9-15.7)$ & $13.9(11.5-17.5)$ & $1.10(0.01-2.40)$ & .004 & .008 \\
\hline hs-CRP, mg/l & $0.36(0.24-0.67)$ & $0.48(0.30-1.58)$ & $0.55(0.27-1.28)$ & $0.07(0.06-0.13)$ & .007 & .048 \\
\hline Albumin, mg/l & $44.5(43.4-46.8)$ & $45.0(44.3-47.2)$ & $46.8(44.7-47.5)$ & $2.30(0.09-2.90)$ & .004 & .030 \\
\hline Cystatin C, mg/dL & $0.84(0.78-0.90)$ & $0.88(0.85-1.00)$ & $0.92(0.87-1.01)$ & $0.04(0.01-0.04)$ & $<.001$ & 0.87 \\
\hline
\end{tabular}


Table 2. Overview of the parameters used to define the metabolic health status

\begin{tabular}{|c|c|c|c|c|c|c|}
\hline & $\begin{array}{c}\text { Normal weight } \\
\text { controls }\end{array}$ & MHO & MUO & RD $(95 \% \mathrm{CI})$ & $P$ value ${ }^{a}$ & $P$ value $^{\mathrm{b}}$ \\
\hline $\mathrm{n}(\%)$ & $212(46.0)$ & $173(38.0)$ & $73(16.0)$ & & & \\
\hline HDL, SDS & $0.11 \pm 0.9$ & $-0.63 \pm 0.73$ & $-1.51(1.03-2.01)$ & $0.88(0.74-1.12)$ & $<.001$ & $<.001$ \\
\hline Triglycerides, SDS & $-0.14 \pm 0.88$ & $0.49(0.17-0.85)$ & $1.78(0.74-2.14)$ & $1.29(0.91-1.38)$ & $<.001$ & $<.001$ \\
\hline Fasting glucose, $\mathrm{mmol} / \mathrm{L}$ & $4.78(4.53-5.01)$ & $4.87(4.70-5.05)$ & $4.95(4.69-5.17)$ & $0.08(0.01-0.19)$ & .009 & .047 \\
\hline Systolic BP, SDS & $-0.02 \pm 0.63$ & $0.18(0.17-0.64)$ & $0.56(0.18-1.10)$ & $0.38(0.07-0.54)$ & $<.001$ & .003 \\
\hline Diastolic BP, SDS & $0.13 \pm 0.47$ & $0.44(0.16-0.76)$ & $0.63(0.24-1.01)$ & $0.19(0.14-0.33)$ & $<.001$ & .002 \\
\hline
\end{tabular}

Data are presented as mean \pm SD or median (interquartile range), item risk difference (RD) between the MHO and MUO groups, confidence interval (CI). comparisons were analyzed by a Mann-Whitney-Wilcoxon test or t-test depending on the distribution of data. aP values for Normal weight vs. MHO vs. MUO. ' $\mathrm{P}$ values for MHO vs. MUO. Abbreviations: MHO, metabolically healthy obesity, MUO, metabolically unhealthy obesity, HDL-C high density lipoprotein cholesterol, BP blood pressure. 
Table 3. Results of hierarchical regression analyses between uric acid-SDS and each parameters used to define metabolic health status

\begin{tabular}{llcc} 
Variables & $\mathbf{R}^{\mathbf{2}}$ & B & $\boldsymbol{P}$ value \\
\hline Fasting glucose, mmol/L & .538 & .135 & $\mathbf{. 0 8 1}$ \\
Triglycerides, SDS & .542 & .269 & $<.001$ \\
HDL, SDS & .768 & -.247 & $<.001$ \\
Systolic BP, SDS & .574 & 2.57 & $<.001$ \\
Diastolic BP, SDS & .626 & 1.87 & $<.001$ \\
Cystatin, mg/dL & .441 & .148 & $<.001$ \\
C-peptide, nmol/L & .559 & .161 & $<.001$ \\
\hline
\end{tabular}

Abbreviations: $\beta=$ regression coefficient, HDL, high-density lipoprotein. All calculations were adjusted for sex and age. 
Table 4. Results of logistic regression models analysis of clinical and metabolic variables including MUO status as the dependent variable

\begin{tabular}{|c|c|c|c|}
\hline Model1 (Nagelkerke R2 0.060) & OR & $95 \%$ CI $\operatorname{Exp}(B)$ & $P$ value \\
\hline Age & 0.98 & $0.8-1.2$ & .777 \\
\hline Female gender & 1.35 & $0.7-2.6$ & .214 \\
\hline \multicolumn{4}{|l|}{ Pubertal development stage } \\
\hline Pre-pubertal & 1.90 & $0.1-4.3$ & .648 \\
\hline Pubertal & 1.40 & $1.1-4.4$ & .010 \\
\hline Waist circumference SDS & 2.50 & $1.2-6.4$ & .017 \\
\hline Model 2 (Nagelkerke R2 0.353) & OR & $95 \%$ CI $\operatorname{Exp}(B)$ & $P$ value \\
\hline Uric acid SDS & 1.61 & $1.1-2.6$ & .004 \\
\hline C-peptide (nmol/l) & 4.05 & $3.5-91$ & .003 \\
\hline Albumin $(\mathrm{g} / \mathrm{l})$ & 0.98 & $0.8-1.2$ & .829 \\
\hline hs-CRP (mg/l) & 0.93 & $0.7-1.1$ & .414 \\
\hline
\end{tabular}

Abbreviations OR = Odds Ratio per unit increase, $\mathrm{CI}=$ Confidence interval, MUO, metabolically unhealthy obesity. Male and postpubertal stage as references. Model 1: unadjusted for confounding factors, Model 2: adjusted for age, sex, pubertal stage and BMI-SDS. 
3 ZUSAMMENFASSUNG DER ARBEIT 
Dissertation zur Erlangung des akademischen Grades Dr. rer. med.

\section{Serum-Harnsäure-Spiegel als Indikator für metabolisch ungesunde Fettleibigkeit bei Kindern und Jugendlichen}

eingereicht von: Edrienny Patrícia Alves Accioly Rocha

angefertigt an: Universität Leipzig, Klinik und Poliklinik für Kinder und Jugendliche der Universität Leipzig in Zusammenarbeit mit LIFE-Child, Leipziger Forschungszentrum für Zivilisationserkrankungen (LIFE)

betreut von: $\quad$ Prof. Dr. med. Wieland Kiess

Dr. rer. med. Mandy Vogel

Eingereicht June 2018

Übergewichtige Personen, die keine fettleibigkeitsbedingten metabolischen Komplikationen zeigen, wurden als "metabolisch gesund fettleibig" (MHO, Metabolically healthy obesity) definiert. Im Gegensatz zu metabolisch ungesunden fettleibigen (MUO, Metabolically unhealthy obesity) Individuen zeigen MHOs keine metabolischen Störungen wie Bluthochdruck, Dyslipidämie, Insulinresistenz und Entzündung [50]. Aufgrund des Mangels an allgemein akzeptierten Kriterien ist die genaue Definition des MHO-Status jedoch immer noch umstritten. Es wird allgemein angenommen, dass die MHO-Definition von der Einführung zusätzlicher Biomarker profitieren könnte, welche wiederum zur Klärung der zugrunde liegenden Mechanismen metabolischer Komplikationen herangezogen werden können [24]. Darüber hinaus hat sich die klinische Forschung hauptsächlich auf Erwachsene konzentriert, und es liegen nur wenige Studien zu MHO bei jungen Menschen vor. Daher wird die Untersuchung des MHO-Status in der jungen Bevölkerung unter Verwendung gut etablierter und potentiell neuer Indikatoren als wesentlich angesehen, um einen positiven Beitrag zur Prävention und/oder Behandlung von zukünftigen fettleibigkeitsbezogenen Krankheiten zu leisten. Unter den möglichen neuen Biomarkern wurde festgestellt, dass Serumharnsäure (Serum-UA) eine wichtige Rolle als kardiometabolischer Risikofaktor [22] für Adipositas-assoziierte Komorbiditäten bei Kindern und Jugendlichen spielt. Dennoch 
haben nur wenige Studien den Zusammenhang zwischen dieser biochemischen Variablen und $\mathrm{MHO}$ in der jungen Bevölkerung untersucht. Der Schwerpunkt der vorliegenden Studie lag auf der Identifizierung potenzieller klinischer und metabolischer Indikatoren, die zur Unterscheidung zwischen MHO- und MUO-Phänotypen beitragen können. Die anthropometrischen, klinischen und biochemischen Merkmale von 458 Kindern und Jugendlichen wurden analysiert und diskutiert. MHO- und MUO-Individuen repräsentieren 38\% bzw. 16\% der dieser Grupe. Der häufigste kardiovaskuläre Risikofaktor bei MUOPatienten war Hypertriglyceridämie (54,2\%), gefolgt von niedrigem Serum-HDL-C (45,8\%), Hypertonie (19,5\%) und gestörter Glukosetoleranz (14,7\%). Zusammenfassend deuten diese Ergebnisse darauf hin, dass eine frühzeitige Identifizierung von MUO in der Jugend möglich ist, wodurch eine frühzeitige Erkennung möglicher metabolischer Komplikationen gewährleistet ist. Verglichen mit der MUO-Gruppe zeigten MHO-Individuen niedrigere Nüchterninsulinwerte, Triglyceride, Blutdruck, Nüchternglucose und höhere Insulinsensitivität sowie niedrigere Serumharnsäure-, hs-CRP-, Albumin- und CPeptidspiegel. Interessanterweise wurden im Gegensatz zu früheren Studien in den MHOund MUO-Gruppen ähnlich hohe Werte für die Marker der Leberfunktion, einschließlich der zirkulierenden Konzentrationen von ALT, AST und alkalischer Phosphatase, festgestellt. Dieses Ergebnis legt nahe, dass niedrigere Leberenzyme zu dem günstigen metabolischen Profil von MHO-Individuen beitragen könnten. Darüber hinaus fördert diese Forschung ein besseres Verständnis der Wirkung potenzieller Indikatoren, die verwendet werden können, um MHO von MUO zu unterscheiden, insbesondere mit dem Fokus auf Serum-UA. Die Ergebnisse dieser Arbeit zeigen, dass Serum-UA mit mehreren kardiometabolischen Risikofaktoren assoziiert ist, die normalerweise mit Fettleibigkeit in Verbindung gebracht werden, wie Serumtriglycerid SDS, systolischer Blutdruck, C-Peptid und Cystatin C. Keine signifikante Beziehung zwischen Glukose-SDS und Serum-UA-Spiegeln wurde gefunden. Höhere Serumspiegel von UA erwiesen sich als signifikanter Indikator für den MUOPhänotyp. Höhere C-Peptid-Spiegel, Taillenumfangs-SDS und Pubertätstadium sind mit einer höheren Wahrscheinlichkeit des MUO-Status assoziiert. Umgekehrt zeigte das Geschlecht der Person keine signifikante Wirkung. Hs-CRP und Albumin waren keine signifikanten MUO-Indikatoren, wenn sie nach Alter, Geschlecht, Pubertät und BMI-SDS kontrolliert wurden. Die in dieser Arbeit präsentierten Ergebnisse könnten für eine bessere Unterscheidung zwischen MUO- und MHO-Phänotypen nützlich sein und adipositasbedingte Komorbiditäten frühzeitig im Leben behandeln. Längsschnittstudien in größeren Kohorten mit jüngeren Individuen werden als ein vernünftiger nächster Schritt 
angesehen, um das Ergebnis dieser Arbeit zu bestätigen und zu erweitern. Mögliche zukünftige Untersuchungen könnten zusätzliche Eigenschaften und Wirkungen von MHO/MUO-Indikatoren betreffen. Zum Beispiel, wie der Serum-UA-Spiegel durch Konsum zuckergesüßter Erfrischungsgetränke und Alkohol beeinfluss wird. 


\section{REFERENCES}

1. Kiess W, Penke M, Sergeyev E, Neef M, Adler M, Gausche R, et al. Childhood obesity at the crossroads. J Pediatr Endocrinol Metab. 2015;28(5-6):481-4. doi: 10.1515/jpem2015-0168. PubMed PMID: 25928753.

2. Lobstein T, Jackson-Leach R, Moodie ML, Hall KD, Gortmaker SL, Swinburn BA, et al. Child and adolescent obesity: Part of a bigger picture. The Lancet. 2015;385(9986):2510-20. doi: 10.1016/S0140-6736(14)61746-3.

3. Reilly JJ, Kelly J. Long-term impact of overweight and obesity in childhood and adolescence on morbidity and premature mortality in adulthood: Systematic review. Int J Obes (Lond). 2011;35(7):891-8. doi: 10.1038/ijo.2010.222. PubMed PMID: 20975725.

4. Ogden CL, Carroll MD, Kit BK, Flegal KM. Prevalence of obesity and trends in body mass index among US children and adolescents, 1999-2010. JAMA. 2012;307(5):48390. doi: 10.1001/jama.2012.40. PubMed PMID: 22253364.

5. Marie $\mathrm{Ng} \mathrm{PhD,} \mathrm{Tom} \mathrm{Fleming} \mathrm{BS,} \mathrm{Margaret} \mathrm{Robinson} \mathrm{BA,} \mathrm{Blake} \mathrm{Thomson} \mathrm{BA,}$ Nicholas Graetz BS, Christopher Margono BS, et al. Global, regional, and national prevalence of overweight and obesity in children and adults during 1980-2013: a systematic analysis for the Global Burden of Disease Study 2013. The Lancet. 2014;384:766-81.

6. Olds T, Maher C, Zumin S, Péneau S, Lioret S, Castetbon K, et al. Evidence that the prevalence of childhood overweight is plateauing: Data from nine countries. Int $\mathbf{J}$ Pediatr Obes. 2011;6(5-6):342-60. doi: 10.3109/17477166.2011.605895. PubMed PMID: 21838570.

7. Lob-Corzilius T. Overweight and obesity in childhood--a special challenge for public health. Int J Hyg Environ Health. 2007;210(5):585-9. doi: 10.1016/j.ijheh.2007.07.019. PubMed PMID: 17889606.

8. Gupta N, Goel K, Shah P, Misra A. Childhood obesity in developing countries: Epidemiology, determinants, and prevention. Endocr Rev. 2012;33(1):48-70. doi: 10.1210/er.2010-0028. PubMed PMID: 22240243.

9. Gray LA, Hernandez Alava M, Kelly MP, Campbell MJ. Family lifestyle dynamics and childhood obesity: Evidence from the millennium cohort study. BMC Public Health. 2018;18(1):500. doi: 10.1186/s12889-018-5398-5. PubMed PMID: 29807535.

10. Lipek T, Igel U, Gausche R, Kiess W, Grande G. Obesogenic environments: 
environmental approaches to obesity prevention. J Pediatr Endocrinol Metab. 2015;28(5-6):485-95. doi: 10.1515/jpem-2015-0127. PubMed PMID: 25928754.

11. Kiess W, Kratzsch J, Sergeyev E, Neef M, Adler M, Pfaeffle R, et al. Metabolic syndrome in childhood and adolescence. Clin Biochem. 2014;47(9):695. doi: 10.1016/j.clinbiochem.2014.05.011. PubMed PMID: 24845708.

12. Bussler S, Penke M, Flemming G, Elhassan YS, Kratzsch J, Sergeyev E, et al. Novel Insights in the Metabolic Syndrome in Childhood and Adolescence. Horm Res Paediatr. 2017;88(3-4):181-93. doi: 10.1159/000479510. PubMed PMID: 28848168.

13. Tamakoshi K, Yatsuya H, Kondo T, Hori Y, Ishikawa M, Zhang H, et al. The metabolic syndrome is associated with elevated circulating C-reactive protein in healthy reference range, a systemic low-grade inflammatory state. Int J Obes Relat Metab Disord. 2003;27(4):443-9. doi: 10.1038/sj.ijo.0802260. PubMed PMID: 12664077.

14. Reinehr T. Metabolic Syndrome in Children and Adolescents: a Critical Approach Considering the Interaction between Pubertal Stage and Insulin Resistance. Curr Diab Rep. 2016;16(1):8. doi: 10.1007/s11892-015-0695-1. PubMed PMID: 26747052.

15. Penke M, Kiess W, Giorgis Td. Non-alcoholic fatty liver disease in children and adolescents. J Pediatr Endocrinol Metab. 2016;29(12):1329-30. doi: 10.1515/jpem2016-0415. PubMed PMID: 27861140.

16. Blüher S. Obesity prevention in childhood and cardiovascular health later in life: We need to get the ball rolling. J Adolesc Health. 2015;56(6):582-3. doi: 10.1016/j.jadohealth.2015.03.013. PubMed PMID: 26003572.

17. Lipek T, Igel U, Gausche R, Kiess W, Grande G. Obesogenic environments: Environmental approaches to obesity prevention. J Pediatr Endocrinol Metab. 2015;28(5-6):485-95. doi: 10.1515/jpem-2015-0127. PubMed PMID: 25928754.

18. Mutlu H, Bilgiç V, Erten S, Aras Ş, Tayfur M. Evaluation of the Relationship between Childhood Traumas and Adulthood Obesity Development. Ecol Food Nutr. 2016;55(4):390-401. doi: 10.1080/03670244.2016.1198791. PubMed PMID: 27399037.

19. DESTATIS, Statistisches Bundesamt. 2014.

20. AstraZeneca Deutschland (2014) Einschätzung der Kostenlast durch Herz-KreislaufErkrankungen - heute und in Zukunft. [cited 2018 Jun 1]. Available from: https://www.astrazeneca.de/einsch\%c3\%a4tzung-der-kostenlast-durch-herzkreislauferkrankungen-heute-und-in-zukunft3.

21. Blüher M. The distinction of metabolically 'healthy' from 'unhealthy' obese individuals. 
Curr Opin Lipidol. 2010;21(1):38-43. doi: 10.1097/MOL.0b013e3283346ccc. PubMed PMID: 19915462.

22. Chen Y, Zhang N, Sun G, Guo X, Yu S, Yang H, et al. Metabolically healthy obesity also has risk for hyperuricemia among Chinese general population: A cross-sectional study. Obes Res Clin Pract. 2016;10 Suppl 1:S84-S95. doi: 10.1016/j.orcp.2016.03.008. PubMed PMID: 27061989.

23. Blüher M. Are there still healthy obese patients? Curr Opin Endocrinol Diabetes Obes. 2012;19(5):341-6. doi: 10.1097/MED.0b013e328357f0a3. PubMed PMID: 22895358.

24. Jung $\mathrm{CH}$, Lee WJ, Song K-H. Metabolically healthy obesity: A friend or foe? Korean J Intern Med. 2017;32(4):611-21. doi: 10.3904/kjim.2016.259. PubMed PMID: 28602062.

25. World Health Organization. Childhood overweight and obesity [cited 2018 May 31]. Available from: http://www.who.int/dietphysicalactivity/childhood/en/.

26. Dietz WH BMC. Introduction: the use of body mass index to assess obesity in children.: Am J Clin Nutr. 1999;70(1):123-5.

27. World Health Organization. WHO | Physical status: the use and interpretation of anthropometry [cited 2018 Jun 1]. Available from: http://www.who.int/childgrowth/publications/physical_status/en/.

28. Kiess W, Hoppmann J, Gesing J, Penke M, Korner A, Kratzsch J, et al. Puberty - genes, environment and clinical issues. J Pediatr Endocrinol Metab. 2016;29(11):1229-31. doi: 10.1515/jpem-2016-0394. PubMed PMID: 27771625.

29. Sims EA. Are there persons who are obese, but metabolically healthy? Metabolism. 2001;50(12):1499-504. doi: 10.1053/meta.2001.27213. PubMed PMID: 11735101.

30. Connelly DM, Taberner PV. Characterization of the spontaneous diabetes obesity syndrome in mature male $\mathrm{CBA} / \mathrm{Ca}$ mice. Pharmacology Biochemistry and Behavior. 1989;34(2):255-9. doi: 10.1016/0091-3057(89)90308-0.

31. Cadenas-Sanchez C, Ruiz JR, Labayen I, Huybrechts I, Manios Y, Gonzalez-Gross M, et al. Prevalence of Metabolically Healthy but Overweight/Obese Phenotype and Its Association With Sedentary Time, Physical Activity, and Fitness. J Adolesc Health. 2017. doi: 10.1016/j.jadohealth.2017.01.018. PubMed PMID: 28363717.

32. Szendroedi J, Kaul K, Kloock L, Straßburger K, Schmid AI, Chmelik M, et al. Lower fasting muscle mitochondrial activity relates to hepatic steatosis in humans. Diabetes Care. 2014;37(2):468-74. doi: 10.2337/dc13-1359. PubMed PMID: 24026561.

33. Hamer M, Johnson W, Bell JA. Improving risk estimates for metabolically healthy 
obesity and mortality using a refined healthy reference group. Eur J Endocrinol. 2017;177(2):169-74. doi: 10.1530/EJE-17-0217. PubMed PMID: 28566442.

34. Mongraw-Chaffin M, Foster MC, Kalyani RR, Vaidya D, Burke GL, Woodward M, et al. Obesity Severity and Duration Are Associated With Incident Metabolic Syndrome: Evidence Against Metabolically Healthy Obesity From the Multi-Ethnic Study of Atherosclerosis. J Clin Endocrinol Metab. 2016;101(11):4117-24. doi: 10.1210/jc.2016-2460. PubMed PMID: 27552544.

35. Blüher S, Schwarz P. Metabolically healthy obesity from childhood to adulthood - Does weight status alone matter? Metabolism. 2014;63(9):1084-92. doi: 10.1016/j.metabol.2014.06.009. PubMed PMID: 25038727.

36. Ingle L, Swainson M, Brodie D, Sandercock GR. Characterization of the metabolically healthy phenotype in overweight and obese British men. Prev Med. 2017;94:7-11. doi: 10.1016/j.ypmed.2016.11.001. PubMed PMID: 27840116.

37. Mangge H, Zelzer S, Puerstner P, Schnedl WJ, Reeves G, Postolache TT, et al. Uric acid best predicts metabolically unhealthy obesity with increased cardiovascular risk in youth and adults. Obesity (Silver Spring). 2013;21(1):E71-7. doi: 10.1002/oby.20061. PubMed PMID: 23401248.

38. Prince RL, Kuk JL, Ambler KA, Dhaliwal J, Ball GDC. Predictors of metabolically healthy obesity in children. Diabetes Care. 2014;37(5):1462-8. doi: 10.2337/dc131697. PubMed PMID: 24574347.

39. Camhi SM, Waring ME, Sisson SB, Hayman LL, Must A. Physical activity and screen time in metabolically healthy obese phenotypes in adolescents and adults. J Obes. 2013;2013:984613. doi: 10.1155/2013/984613. PubMed PMID: 24102022.

40. Reinehr T, Wolters B, Knop C, Lass N, Holl RW. Strong effect of pubertal status on metabolic health in obese children: a longitudinal study. J Clin Endocrinol Metab. 2015;100(1):301-8. doi: 10.1210/jc.2014-2674. PubMed PMID: 25243573.

41. Weghuber D, Zelzer S, Stelzer I, Paulmichl K, Kammerhofer D, Schnedl W, et al. High risk vs. "metabolically healthy" phenotype in juvenile obesity - neck subcutaneous adipose tissue and serum uric acid are clinically relevant. Exp Clin Endocrinol Diabetes. 2013;121(7):384-90. doi: 10.1055/s-0033-1341440. PubMed PMID: 23519645.

42. Kelishadi R, Cook SR, Motlagh ME, Gouya MM, Ardalan G, Motaghian M, et al. Metabolically obese normal weight and phenotypically obese metabolically normal youths: The CASPIAN Study. J Am Diet Assoc. 2008;108(1):82-90. 
doi: 10.1016/j.jada.2007.10.013. PubMed PMID: 18155992.

43. Sénéchal M, Wicklow B, Wittmeier K, Hay J, MacIntosh AC, Eskicioglu P, et al. Cardiorespiratory fitness and adiposity in metabolically healthy overweight and obese youth. Pediatrics. 2013;132(1):e85-92. doi: 10.1542/peds.2013-0296. PubMed PMID: 23796736.

44. Primeau V, Coderre L, Karelis AD, Brochu M, Lavoie M-E, Messier V, et al. Characterizing the profile of obese patients who are metabolically healthy. Int $\mathrm{J}$ Obes (Lond). 2011;35(7):971-81. doi: 10.1038/ijo.2010.216. PubMed PMID: 20975726.

45. Rey-Lopez JP, Rezende LF de, Pastor-Valero M, Tess BH. The prevalence of metabolically healthy obesity: a systematic review and critical evaluation of the definitions used. Obes Rev. 2014;15(10):781-90. doi: 10.1111/obr.12198. PubMed PMID: 25040597.

46. Bervoets L, Massa G. Classification and clinical characterization of metabolically "healthy" obese children and adolescents. J Pediatr Endocrinol Metab. 2016;29(5):55360. doi: 10.1515/jpem-2015-0395. PubMed PMID: 26910741.

47. Landgraf K, Schuster S, Meusel A, Garten A, Riemer T, Schleinitz D, et al. Short-term overfeeding of zebrafish with normal or high-fat diet as a model for the development of metabolically healthy versus unhealthy obesity. BMC Physiol. 2017;17(1):4. doi: 10.1186/s12899-017-0031-x. PubMed PMID: 28327129.

48. Diniz, Maria de Fatima Haueisen Sander, Beleigoli AMR, Ribeiro ALP, Vidigal PG, Bensenor IM, Lotufo PA, et al. Factors associated with metabolically healthy status in obesity, overweight, and normal weight at baseline of ELSA-Brasil. Medicine (Baltimore). 2016;95(27):e4010. doi: 10.1097/MD.0000000000004010. PubMed PMID: 27755484.

49. Liu Z, Que S, Zhou L, Zheng S. Dose-response Relationship of Serum Uric Acid with Metabolic Syndrome and Non-alcoholic Fatty Liver Disease Incidence: A Metaanalysis of Prospective Studies. Sci Rep. 2015;5:14325. doi: 10.1038/srep14325. PubMed PMID: 26395162.

50. Blüher M. Are metabolically healthy obese individuals really healthy? Eur J Endocrinol. 2014;171(6):R209-19. doi: 10.1530/EJE-14-0540. PubMed PMID: 25012199.

51. Phillips CM, Perry IJ. Does inflammation determine metabolic health status in obese and nonobese adults? J Clin Endocrinol Metab. 2013;98(10):E1610-9. doi: 10.1210/jc.2013-2038. PubMed PMID: 23979951. 
52. Hashimoto Y, Tanaka M, Kimura T, Kitagawa N, Hamaguchi M, Asano M, et al. Hemoglobin concentration and incident metabolic syndrome: a population-based largescale cohort study. Endocrine. 2015;50(2):390-6. doi: 10.1007/s12020-015-0587-9. PubMed PMID: 25863486.

53. Chima RS, LaMontagne T, Piraino G, Hake PW, Denenberg A, Zingarelli B. C-peptide, a novel inhibitor of lung inflammation following hemorrhagic shock. Am J Physiol Lung Cell Mol Physiol. 2011;300(5):L730-9. doi: 10.1152/ajplung.00308.2010. PubMed PMID: 21398498.

54. Cardellini M, Farcomeni A, Ballanti M, Morelli M, Davato F, Cardolini I, et al. Cpeptide: A predictor of cardiovascular mortality in subjects with established atherosclerotic disease. Diab Vasc Dis Res. 2017:1479164117710446. doi: 10.1177/1479164117710446. PubMed PMID: 28565926.

55. Malkin AJ, Kuznetsov YG, McPherson A. In situ atomic force microscopy studies of surface morphology, growth kinetics, defect structure and dissolution in macromolecular crystallization. Journal of Crystal Growth. 1999;196(2-4):471-88. doi: 10.1016/S0022-0248(98)00823-9.

56. Malkin AJ, Kuznetsov YG, McPherson A. Incorporation of microcrystals by growing protein and virus crystals. Proteins. 1996;24(2):247-52. doi: 10.1002/(SICI)10970134(199602)24:2<247:AID-PROT11>3.0.CO;2-N.

57. Stephen D Durbin, Warren E Carlson and Misa T Saros. In situ studies of protein crystal growth by atomic force microscopy: J. Phys. 1993;26:B125-B132.

58. Matsushige K, Hamano T, Horiuchi T. Atomic force microscopy observation of the epitaxial growth of organic molecules. Journal of Crystal Growth. 1995;146(1-4):6414. doi: 10.1016/0022-0248(94)00532-X.

59. Guo HM, Liu HW, Wang YL, Gao HJ, Gong Y, Jiang HY, et al. Surface structures of dl-valine and 1-alanine crystals observed by atomic force microscopy at a molecular resolution. Surface Science. 2004;552(1-3):70-6. doi: 10.1016/j.susc.2003.12.049.

60. Salvatore J. Bonafede/Michael D. Ward. Selective Nucleation and Growth of an Organic Polymorph by Ledge-Directed Epitaxy on a Molecular Crystal Substrate.

61. Kang D-H, Ha S-K. Uric Acid Puzzle: Dual Role as Anti-oxidantand Pro-oxidant. Electrolyte Blood Press. 2014;12(1):1-6. doi: 10.5049/EBP.2014.12.1.1. PubMed PMID: 25061467.

62. Johnson RJ, Rideout BA. Uric acid and diet--insights into the epidemic of cardiovascular disease. N Engl J Med. 2004;350(11):1071-3. 
doi: 10.1056/NEJMp048015. PubMed PMID: 15014177.

63. Wood I. Review article: Landscapes compared. Early Medieval Europe. 2007;15(2):223-37. doi: 10.1111/j.1468-0254.2007.00204.x.

64. Johnson RJ, Titte S, Cade JR, Rideout BA, Oliver WJ. Uric acid, evolution and primitive cultures. Seminars in Nephrology. 2005;25(1):3-8. doi: 10.1016/j.semnephrol.2004.09.002.

65. Feig DI. Hyperuricemia and hypertension. Adv Chronic Kidney Dis. 2012;19(6):37785. doi: 10.1053/j.ackd.2012.05.009. PubMed PMID: 23089272.

66. Sundy JS, Hershfield MS. Uricase and other novel agents for the management of patients with treatment-failure gout. Curr Rheumatol Rep. 2007;9(3):258-64. doi: 10.1007/s11926-007-0041-y.

67. Kolderup A, Svihus B. Fructose Metabolism and Relation to Atherosclerosis, Type 2 Diabetes, and Obesity. J Nutr Metab. 2015;2015:823081. doi: 10.1155/2015/823081. PubMed PMID: 26199742.

68. Sautin YY, Johnson RJ. Uric acid: The oxidant-antioxidant paradox. Nucleosides Nucleotides Nucleic Acids. 2008;27(6):608-19. doi: 10.1080/15257770802138558. PubMed PMID: 18600514.

69. Takahashi S, Yamamoto T, Moriwaki Y, Tsutsumi Z, Higashino K. Increased concentrations of serum $\mathrm{Lp}$ (a) lipoprotein in patients with primary gout. Annals of the Rheumatic Diseases. 1995;54(2):90-3. doi: 10.1136/ard.54.2.90.

70. Villegas R, Xiang Y-B, Elasy T, Xu WH, Cai H, Cai Q, et al. Purine-rich foods, protein intake, and the prevalence of hyperuricemia: The Shanghai Men's Health Study. Nutr Metab Cardiovasc Dis. 2012;22(5):409-16. doi: 10.1016/j.numecd.2010.07.012. PubMed PMID: 21277179.

71. Kylin E. Studien ueber das hypertonie-hyperglykamie-hyperurikamiesyndrom. Zentralblatt für innere Medizin: Scientific Research Publishing.

72. Liou T-L, Lin M-W, Hsiao L-C, Tsai T-T, Chan W-L, Ho L-T, et al. Is Hyperuricemia Another Facet of the Metabolic Syndrome? Journal of the Chinese Medical Association. 2006;69(3):104-9. doi: 10.1016/S1726-4901(09)70186-8.

73. ZAVARONI I, MAZZA S, FANTUZZI M, DALL'AGLIO E, BONORA E, DELSIGNORE R, et al. Changes in insulin and lipid metabolism in males with asymptomatic hyperuricaemia. J Intern Med. 1993;234(1):25-30. doi: 10.1111/j.13652796.1993.tb00700.x.

74. Choi HK, Ford ES. Prevalence of the metabolic syndrome in individuals with 
hyperuricemia. Am J Med. 2007;120(5):442-7. doi: 10.1016/j.amjmed.2006.06.040. PubMed PMID: 17466656.

75. P C, al e. Community-based epidemiological study on hyperuricemia in Pu-Li, Taiwan: J Formos Med Assoc.

76. Liu M, He Y, Jiang B, Wu L, Yang S, Wang Y, et al. Association between Serum Uric Acid Level and Metabolic Syndrome and Its Sex Difference in a Chinese Community Elderly Population. Int J Endocrinol. 2014;2014:754678. doi: 10.1155/2014/754678. PubMed PMID: 25136366.

77. Chen LY, Zhu WH, Chen ZW, Dai HL, Ren JJ, Chen JH, Chen LQ, Fang LZ (Relationship between hyperuricemia and metabolic syndrome: Zhejiang Univ Sci.

78. Wei C-Y, Sun C-C, Wei JC-C, Tai H-C, Sun C-A, Chung C-F, et al. Association between Hyperuricemia and Metabolic Syndrome: An Epidemiological Study of a Labor Force Population in Taiwan. Biomed Res Int. 2015;2015:369179. doi: 10.1155/2015/369179. PubMed PMID: 26273611.

79. Gustafsson D, Unwin R. The pathophysiology of hyperuricaemia and its possible relationship to cardiovascular disease, morbidity and mortality. BMC Nephrol. 2013;14:164. doi: 10.1186/1471-2369-14-164. PubMed PMID: 23895142.

80. Weiler B. Review article: Power and politics in medieval history, c.850-c.1170. Early Medieval Europe. 2008;16(4):477-93. doi: 10.1111/j.1468-0254.2008.00239.x.

81. Sun D, Li S, Zhang X, Fernandez C, Chen W, Srinivasan SR, et al. Uric acid is associated with metabolic syndrome in children and adults in a community: The Bogalusa Heart Study. PLoS One. 2014;9(10):e89696. doi: 10.1371/journal.pone.0089696. PubMed PMID: 25343690.

82. Perez ES, Medina MAG, Lomeli ML-C, González VT, Pérez JZV, Lavalle González FJ, et al. Association between serum uric acid and metabolic syndrome components in prepubertal obese children (Tanner Stage I) from Nuevo León, Mexico - a preliminary study. BMC Obes. 2017;4:25. doi: 10.1186/s40608-017-0160-6. PubMed PMID: 28690854.

83. Cardoso AS, Gonzaga NC, Medeiros CCM, Carvalho DFd. Association of uric acid levels with components of metabolic syndrome and non-alcoholic fatty liver disease in overweight or obese children and adolescents. J Pediatr (Rio J). 2013;89(4):412-8. doi: 10.1016/j.jped.2012.12.008. PubMed PMID: 23791233.

84. Jones DP, Richey PA, Alpert BS, Li R. Serum uric acid and ambulatory blood pressure in children with primary hypertension. Pediatr Res. 2008;64(5):556-61. 
doi: 10.1203/PDR.0b013e318183fd7c. PubMed PMID: 18596575.

85. Su P, Hong L, Zhao Y, Sun H, Li L. The Association Between Hyperuricemia and Hematological Indicators in a Chinese Adult Population. Medicine (Baltimore). 2016;95(7):e2822. doi: 10.1097/MD.0000000000002822. PubMed PMID: 26886635.

86. Johnson RJ, Nakagawa T, Sanchez-Lozada LG, Shafiu M, Sundaram S, Le M, et al. Sugar, uric acid, and the etiology of diabetes and obesity. Diabetes. 2013;62(10):330715. doi: 10.2337/db12-1814. PubMed PMID: 24065788.

87. Andrade JAM, Kang HC, Greffin S, Garcia Rosa ML, Lugon JR. Serum uric acid and disorders of glucose metabolism: The role of glycosuria. Braz J Med Biol Res. 2014;47(10):917-23. doi: 10.1590/1414-431X20143878.

88. Meisinger C, Thorand B, Schneider A, Stieber J, Döring A, Löwel H. Sex Differences in Risk Factors for Incident Type 2 Diabetes Mellitus. Arch Intern Med. 2002;162(1):82. doi: 10.1001/archinte.162.1.82.

89. Gil-Campos M, Aguilera. C.M, Canete R, Gil A. Uric acid is associated with features of insulin resistance syndrome in obese children at prepubertal stage. Nutr Hosp. 2009;24(5):607-13.

90. Quinones Galvan A, Natali A, Baldi S, Frascerra S, Sanna G, Ciociaro D. Effect of insulin on uric acid excretion in humans: Am J Physiol. 1995;268:E1-5.

91. Gao X, Zhang W, Wang Y, Pedram P, Cahill F, Zhai G, et al. Serum metabolic biomarkers distinguish metabolically healthy peripherally obese from unhealthy centrally obese individuals. Nutr Metab (Lond). 2016;13:33. doi: 10.1186/s12986-0160095-9. PubMed PMID: 27175209.

92. Viazzi F, Antolini L , Giussani M, Brambilla P, Mastriani S, Pontremoli A. S., Valsecchi M. G. Serum Uric Acid and Blood Pressure in Children at Cardiovascular Risk: Pediatrics. 2013;1(e84-e89).

93. Mazzali M, Hughes J, Kim Y-G, Jefferson JA, Kang D-H, Gordon KL, et al. Elevated Uric Acid Increases Blood Pressure in the Rat by a Novel Crystal-Independent Mechanism. Hypertension. 2001;38(5):1101-6. doi: 10.1161/hy1101.092839.

94. Balda, C. A, Plavnik F L, Tavarres A. Uric acid and systemic arterial hypertension evidences and controversies: J Bras Nefrol. 2012;24(3):147-52.

95. Kuwabara M. Hyperuricemia, Cardiovascular Disease, and Hypertension. Pulse (Basel). 2016;3(3-4):242-52. doi: 10.1159/000443769. PubMed PMID: 27195245.

96. Kang D-H, Park S-K, Lee I-K, Johnson RJ. Uric acid-induced C-reactive protein expression: Implication on cell proliferation and nitric oxide production of human 
vascular cells. J Am Soc Nephrol. 2005;16(12):3553-62. doi: 10.1681/ASN.2005050572. PubMed PMID: 16251237.

97. Ruggiero C, Cherubini A, Ble A, Bos AJG, Maggio M, Dixit VD, et al. Uric acid and inflammatory markers. Eur Heart J. 2006;27(10):1174-81. doi: 10.1093/eurheartj/ehi879. PubMed PMID: 16611671.

98. Silva HAd, Carraro JCC, Bressan J, Hermsdorff HHM. Relation between uric acid and metabolic syndrome in subjects with cardiometabolic risk. Einstein (Sao Paulo). 2015;13(2):202-8. doi: 10.1590/S1679-45082015AO3194. PubMed PMID: 26018145.

99. Fouad M, Fathy H, Zidan A. Serum uric acid and its association with hypertension, early nephropathy and chronic kidney disease in type 2 diabetic patients. J Bras Nefrol. 2016;38(4):403-10. doi: 10.5935/0101-2800.20160065. PubMed PMID: 28001185.

100. Bobulescu IA, Moe OW. Renal transport of uric acid: Evolving concepts and uncertainties. Adv Chronic Kidney Dis. 2012;19(6):358-71. doi: 10.1053/j.ackd.2012.07.009. PubMed PMID: 23089270.

101. Choi HK, Curhan G. Soft drinks, fructose consumption, and the risk of gout in men: Prospective cohort study. BMJ. 2008;336(7639):309-12. doi: 10.1136/bmj.39449.819271.BE. PubMed PMID: 18244959.

102. Krishnan E, Pandya BJ, Chung L, Hariri A, Dabbous O. Hyperuricemia in young adults and risk of insulin resistance, prediabetes, and diabetes: A 15-year follow-up study. Am J Epidemiol. 2012;176(2):108-16. doi: 10.1093/aje/kws002. PubMed PMID: 22753829.

103. Kanbay M, Jensen T, Solak Y, Le M, Roncal-Jimenez C, Rivard C, et al. Uric acid in metabolic syndrome: From an innocent bystander to a central player. Eur J Intern Med. 2016;29:3-8. doi: 10.1016/j.ejim.2015.11.026. PubMed PMID: 26703429.

104. Johnson RJ, Nakagawa T, Jalal D, Sánchez-Lozada LG, Kang D-H, Ritz E. Uric acid and chronic kidney disease: Which is chasing which? Nephrol Dial Transplant. 2013;28(9):2221-8. doi: 10.1093/ndt/gft029. PubMed PMID: 23543594.

105. Harada M, Izawa A, Hidaka H, Nakanishi K, Terasawa F, Motoki H, et al. Importance of cystatin $\mathrm{C}$ and uric acid levels in the association of cardiometabolic risk factors in Japanese junior high school students. J Cardiol. 2017;69(1):222-7. doi: 10.1016/j.jjcc.2016.03.013. PubMed PMID: 27138369.

106. Hayashino Y, Okamura S, Tsujii S, Ishii H. Association of serum uric acid levels with the risk of development or progression of albuminuria among Japanese patients with type 2 diabetes: a prospective cohort study Diabetes Distress and Care Registry at Tenri 
(DDCRT 10). Acta Diabetol. 2016;53(4):599-607. doi: 10.1007/s00592-015-0825-x. PubMed PMID: 26935413.

107. Kuroczycka-Saniutycz E, Porowski T, Protas PT, Pszczółkowska M, Porowska H, Kirejczyk JK, et al. Does obesity or hyperuricemia influence lithogenic risk profile in children with urolithiasis? Pediatr Nephrol. 2015;30(5):797-803. doi: 10.1007/s00467014-2999-9. PubMed PMID: 25380789.

108. Fini MA, Wright RM, Stenmark KR, Daniels SR, Johnson RJ. Is uric acid an underdiagnosed mediator of adverse outcome in metabolically healthy overweight/obese individuals? Am J Med. 2014;127(6):e21. doi: 10.1016/j.amjmed.2014.02.031. PubMed PMID: 24856327.

109. Quante M, Hesse M, Dohnert M, Fuchs M, Hirsch C, Sergeyev E, et al. The LIFE child study: a life course approach to disease and health. BMC Public Health. 2012;12:1021. doi: 10.1186/1471-2458-12-1021. PubMed PMID: 23181778. 


\section{ANLAGEN}

\section{Supplement Material}

Serum uric acid levels as an indicator for metabolically unhealthy obesity in children and adolescents

Edrienny Patrícia Alves Accioly Rocha', Mandy Vogel, Juraj Stanik, Diana Pietzner, Anja Willenberg, Antje Körner, Wieland Kiess

2 Tables 
Table 1. Metabolic healthy status

\begin{tabular}{|c|c|c|c|}
\hline \multirow[t]{8}{*}{ Criteria } & Cardiovascular risk factors (CRF) & MHO & MUO \\
\hline & & No CRF & $<2$ of the CRF \\
\hline & Hypertension: & & \\
\hline & $\mathrm{SBP} \geq 95$ th percentile or & & \\
\hline & $\mathrm{DBP} \geq 95$ th percentile & & \\
\hline & Dyslipidemia: & & \\
\hline & $\begin{array}{l}\mathrm{TG} \geq 95 \text { th percentile or } \mathrm{HDL}-\mathrm{C}<5 \text { th } \\
\text { percentile }\end{array}$ & & \\
\hline & Impaired fasting glucose $\geq 5.6 \mathrm{mmol} / \mathrm{L}$ & & \\
\hline
\end{tabular}

MHO - Metabolically healthy Obesity; MUO - Metabolically unhealthy Obesity; SBP - Systolic blood pressure; DBP diastolic blood pressure; TG - Triglycerides; HDL-C High density cholesterol 
Table 2. Anthropometric and biochemical characteristics of normal weight controls, MHO and MUO children

\begin{tabular}{|c|c|c|c|c|c|c|}
\hline & $\begin{array}{l}\text { Normal weight } \\
\text { controls }\end{array}$ & MHO & MUO & RD $(95 \%$ CI $)$ & $\begin{array}{c}P \\
\text { value }^{\mathrm{a}}\end{array}$ & $P$ value $^{\mathrm{b}}$ \\
\hline $\mathrm{n}(\%)$ & $212(46.0)$ & $173(38.0)$ & $73(16.0)$ & & & \\
\hline \multicolumn{7}{|c|}{ Baseline characteristics, anthropometric } \\
\hline Age, years & $11.1 \pm 2.98$ & $11.2 \pm 2.64$ & $11.4 \pm 2.84$ & $0.20(0.03-0.98)$ & .610 & .785 \\
\hline Male sex, n (\%) & $109(51)$ & $96(55)$ & $34(49)$ & & .496 & .496 \\
\hline waist to height ratio, $\mathrm{cm}$ & $0.42 \pm 0.03$ & $0.54(0.51-0.58)$ & $0.56(0.53-0.61)$ & $0.02(0.00-0.04)$ & $<.001$ & .004 \\
\hline $\begin{array}{l}\text { Neck circumference, } \\
\text { SDS }\end{array}$ & $-0.12 \pm 0.78$ & $1.37(0.95-1.72)$ & $1.54(1.04-2.10)$ & $0.17(0.02-0.41)$ & $<.001$ & .006 \\
\hline \multicolumn{7}{|l|}{ Biochemical parameters } \\
\hline $\begin{array}{l}\text { Total-cholesterol, } \\
\mathrm{mmol} / \mathrm{L}\end{array}$ & $4.04(3.68-4.52)$ & $4.11(3.71-4.65)$ & $4.37(3.88-4.99)$ & $\begin{array}{l}0.26(0.01- \\
0.45)\end{array}$ & .043 & .039 \\
\hline LDL-C, mmol/L & $2.23(1.87-2.64)$ & $2.43(2.05-2.84)$ & $2.73(2.26-3.17)$ & $\begin{array}{l}0.30(0.08- \\
0.46)\end{array}$ & $<.001$ & .004 \\
\hline Fasting insulin, $\mu \mathrm{U} / \mathrm{L}$ & $7.86(5.55-10.3)$ & $14.2(11.0-16.8)$ & $17.3(13.0-20.3)$ & $\begin{array}{l}3.10(4.42- \\
9.64)\end{array}$ & $<.001$ & $<.001$ \\
\hline $\mathrm{HbA} 1 \mathrm{C}, \%$ & $5.02 \pm 0.31$ & $5.08 \pm 0.36$ & $5.12(4.91-5.30)$ & $0.04(0.02-0.13)$ & .033 & .379 \\
\hline Haemoglobin, g/dL & $13.07 \pm 0.94$ & $12.8 \pm 1.02$ & $13.1(12.6-13.5)$ & $0.30(0.00-0.50)$ & .210 & .429 \\
\hline Red blood cell, $10^{\wedge} 12$ & $4.70 \pm 0.33$ & $4.72 \pm 1.56$ & $4.76(4.54-4.95)$ & $0.04(0.04-0.13)$ & .131 & .078 \\
\hline Hematocrit, \% & $0.38(0.36-0.39)$ & $0.37(0.36-0.40)$ & $0.38(0.37-0.40)$ & $0.01(0.00-0.01)$ & .561 & .339 \\
\hline White blood cell, $10^{\wedge} 9 \mathrm{~L}$ & $5.74 \pm 1.55$ & $6.45 \pm 1.56$ & $6.60(5.80-7.60)$ & $0.15(0.79-0.99)$ & $<0.001$ & .133 \\
\hline Platelet, $10^{\wedge} 9 \mathrm{~L}$ & $279.2 \pm 58.8$ & $274(248-315)$ & $286(264-331)$ & $12.0(2.99-32.0)$ & .040 & .052 \\
\hline Neutrophils, 10^9L & $2.48(2.01-3.12)$ & $3.22(2.56-3.96)$ & $3.65(2.44-4.31)$ & $\begin{array}{l}0.43(0.12- \\
0.63)\end{array}$ & .002 & .173 \\
\hline Monocyte, $10^{\wedge} 9 \mathrm{~L}$ & $0.49(0.38-0.57)$ & $0.51(0.42-0.63)$ & $0.50(0.42-0.62)$ & $0.01 \quad(0.12-0.63)$ & .012 & .907 \\
\hline $\begin{array}{l}\text { Alkaline phosphatase, } \\
\text { U/l }\end{array}$ & $3.65 \pm 1.46$ & $4.01(3.23-4.62)$ & $4.40(2.59-5.02)$ & $0.39(0.23-0.54)$ & .029 & .442 \\
\hline Total protein $(\mathrm{g} / \mathrm{l})$ & $68.1 \pm 4.30$ & $70.4 \pm 3.53$ & $70.7(68.2-72.6)$ & $0.30(0.30-1.40)$ & .002 & .264 \\
\hline Creatine kinase, $\mu \mathrm{kat} / \mathrm{l}$ & $1.99(1.55-2.71)$ & $1.89(1.49-2.45)$ & $1.79(1.55-2.49)$ & $0.18(0.10-0.28)$ & .108 & .864 \\
\hline Lpa-Lipoprotein-a, g/l & $0.09(0.04-0.29)$ & $0.10(0.03-0.31)$ & $0.07(0.03-0.20)$ & $0.03(0.00-0.04)$ & .517 & .211 \\
\hline Interleukin 6, pg ml & $1.76(1.50-3.07)$ & $1.50(1.50-2.78)$ & $1.86(1.50-3.01)$ & $0.36(0.01-0.50)$ & .723 & .325 \\
\hline Testosterone, nmol/l & $0.40(0.08-2.28)$ & $0.39(0.08-0.98)$ & $0.37(0.11-1.32)$ & $0.02(0.08-0.22)$ & .968 & .931 \\
\hline Estradiol, pmol/l & $35.8(18.4-115.5)$ & $18.4(17.0-94.4)$ & $41.6(16.4-86.8)$ & $23.2(0.02-21.1)$ & .050 & .042 \\
\hline Shbg, nmol/1 & $77.5(47.3-116)$ & $92.1(60.5-130)$ & $78.2(42.2-117)$ & $13.9(27.2-39.0)$ & .123 & .158 \\
\hline
\end{tabular}

Data are presented as mean \pm SD or median (interquartile range), item risk difference (RD) between the MHO and MUO groups, confidence interval (CI).

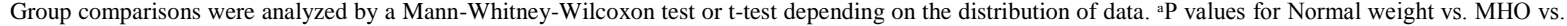
MUO. ${ }^{b} \mathrm{P}$ values for MHO vs. MUO. Abbreviations: MHO, metabolically healthy obesity, MUO, metabolically unhealthy obesity, LDL-C low high density lipoprotein cholesterol, ALT alanine aminotransferase, AST aspartate aminotransferase, GGT gammaglutamyltransferase, HbA1c glycated hemoglobin A1c, Lp(a) Lipoprotein-a, hs-CRP high sensitivity C-reactive protein. 


\section{Erklärung über die eigenständige Abfassung der Arbeit}

Hiermit erkläre ich, dass ich die vorliegende Arbeit selbstständig und ohne unzulässige Hilfe oder Benutzung anderer als der angegebenen Hilfsmittel angefertigt habe. Ich versichere, dass Dritte von mir weder unmittelbar noch mittelbar eine Vergütung oder geldwerte Leistungen für Arbeiten erhalten haben, die im Zusammenhang mit dem Inhalt der vorgelegten Dissertation stehen, und dass die vorgelegte Arbeit weder im Inland noch im Ausland in gleicher oder ähnlicher Form einer anderen Prüfungs-behörde zum Zweck einer Promotion oder eines anderen Prüfungsverfahrens vorgelegt wurde. Alles aus anderen Quellen und von anderen Personen übernommene Material, das in der Arbeit verwendet wurde oder auf das direkt Bezug genommen wird, wurde als solches kenntlich gemacht. Insbesondere wurden alle Personen genannt, die direkt an der Entstehung der vorliegenden Arbeit beteiligt waren. Die aktuellen gesetzlichen Vorgaben in Bezug auf die Zulassung der klinischen Studien, die Bestimmungen des Tierschutzgesetzes, die Bestimmungen des Gentechnikgesetzes und die allgemeinen Datenschutzbestimmungen wurden eingehalten. Ich versichere, dass ich die Regelungen der Satzung der Universität Leipzig zur Sicherung guter wissenschaftlicher Praxis kenne und eingehalten habe. 


\section{Curriculum Vitae}

Persönliche Daten

Edrienny Patrícia Alves Accioly Rocha

Geboren am 10.07.1984 in Recife - Pernambuco - Brasilien

Ausbildung

Seit $10 / 2014$

Promotion in Medizin: Universität Leipzig

- Doktorvater: Prof. Wieland Kiess, Direktor der Klinik für Kinder und Jugendmedizin, Uni-Leipzig.

$03 / 2012-02 / 2014$

Master in Krankenpflege: Universidade de Pernambuco Pernambuco - Brasilien.

- Verbundprogram für den postgraduierten Studiengang der Krankenpflege.

- Masterarbeit: Hohes Risiko für Typ-2-Diabetes mellitus bei Kindern und Jugendlichen mit Adipositas oder Übergewicht.

02/2008 - 02/2012 Lehrlizenz : Universidade Federal de Pernambuco - Pernambuco Brasilien.

- Verleiht den Titel: Hochschulabsolvent - Magistererium. Erfolgreicher Abschluss zur Krankenpflege (eine Lizenz zum Lehren).

02/2007 - 02/2012 Bachelor: Universidade Federal de Pernambuco - Pernambuco Brasilien.

- Erfolgreicher Abschluss zur Krankenpflege.

Praxiserfahrungen

04/2013 - 05/2014 Lehrer für die Ausbildung zur Krankenpflege (Hochschule) Pernambuco - Brasilien.

- chirurgische Krankenpflege, psychiatrische Krankenflege, Kind und maternale Krankeflege. 
05/2012 - 05/2013 Lehrer der Krankenhauspraxis von Studenten im 5. Semester des grundständigen Programms in der Abteilung der öffentlichen Krankenpflege - Universität Pernambuco - Brasilien.

09/2012 - 10/2013 Krankenschwester im Hospital IMIP - Pernambuco, Brasilien.

- Arbeit in der stationären Einheit mit Kinder als Patienten mit Herzerkrankungen und in der Intensivstation.

02/2012 - 12/2012 Krankenschwester im Hospital das Clinicas - Pernambuco Brasilien.

Stipendia

- Arbeit in der Onkologie mit erwachsenen Patienten.

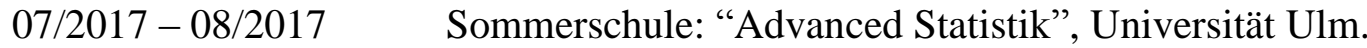

01/2013 - 02/2013 Public Health Collaborative Field Course, David Rockefeller

Center for Latin American Studies (DRCLAS), Harvard

University.

06/2012 - 07/2012 Medizinische Sommerschule, Perspektiven für die globale

Gesundheit im 21. Jahrhundert - Universität Ulm. Deutschland.

Sprachkenntnisse

Portugiesisch (Muttersprache) Englisch (sehr gute Kenntnisse)

Spanisch (sehr gute Kenntnisse) Deutsch (gute Kenntnisse)

\section{Computerkenntnisse}

Microsoft Office (gute Kenntnisse)

R studio Software (Grundkenntnisse)

SPSS Software (Grundkenntnisse)

Leipzig, 
V. List of publications and conference participations

$\underline{\text { Publications of the dissertation }}$

Rocha, Edrienny P.A .A. Vogel, Mandy, Stanik, Juraj, Körner, Antje, Kiess, Wieland. Serum uric acid levels as an indicator for metabolically unhealthy obesity in children and adolescents. Hormone pediatric research

\section{Other Publication}

De Aquino, Camila A, Rocha, Edrienny P.A .A., Nascimento, Eloine, A. Pilgrimage (Via Crucis) to the diagnosis of leprosy (2015), Ver enferm UERJ, Rio de Janeiro, 2015 mar/abr; 23(2):185-190.

Posters in international conferences

E.A.A. Rocha, M. Voge, J. Stanik, A. Körner, W. Kiess: Serum acid uric levels as an indicator for metabolically unhealthy obesity in youth: results from a population-based cohort in Germany". Absctract und Poster, 54th EASD Annual Meeting which will be held in Berlin, from 1 - 5 October 2018. 


\section{Acknowledgments}

I am sincerely grateful for my supervisor Prof. Kiess, who not only accepted me as a Ph.D. student here in Germany, but also offered me the opportunity to become part of the LIFEChild Team through my dissertation. He helped me through my professional growth during the years and taught me about scientific research. His way of encouraging me towards independent work was essential to this research.

My profound gratitude to Dr. Mandy Vogel, who made this extensive statistical project possible. Thanks to her aid, I could walk through the jungle of data and results. Not to mention that her clear view to my work improved a lot the quality of this study, as well as her support, time and encouragement. Furthermore, I would like to thank all of the LIFE Child team, without whose daily work and effort this study would not have been possible.

I also thank Dr. Juraj Stanik, Dr. Diana Pietzner, Dr. Anja Willenberg for their advices and review of the manuscripts. In addition, I would like to thank Prof. Dr. Körner for her warm and professional support.

I would also like to thank all my friends particularly the Brazilian in Germany (Fred, Rejane, Patrícia, Matheus, Murilo and Yan), nonbrazilian in Germany (Phillip, Rito, Daria, my dear Natascha, Debora, Chiara), nonbrazilian around the world (Sarina, Anna, Lydia, Tebogo), German in Germany (Charlotte, Eva, Imanuel, Selma, Anett, Lea, Josi, Conny, Mandy), and Brazilian in Brazil (Camilla, Alamo, Cássia, André, Carol, Bruno, Samantha, Juliana, Tabata, Dreyd, Gisele, Leilane) who have been very supportive in recent years and who were there to listen.

I deeply thank my friends and reviewers, Karsten Przybilla, Dr. Alexandra and Dr. Daniele for their valuable advice and constructive criticism both in the data analysis and the text that helped notably to improve my work. Yours expert advice and help have been very useful to me in many matters.

Merci beaucoup to Hugo Mahiou who has stood by me in recent years and has been a constant source of support during our studies, most recently during the $\mathrm{Ph} . \mathrm{D}$. phase, as well as for his great care, patience and unimpeded belief in me.

My deepest gratitude is to Henrique Vitorio who helped me make the accomplishment of my Ph.D. possible. Thank you so much for your love and for being my support at all times.

There are many people at the University of Leipzig and the Ph.D. group at the LIFE-Child, who have made this work possible and are not listed. My warm thanks to all of them for the support they provided me over the years. I am grateful to every participant who gave up their 
time to allow this $\mathrm{PhD}$ to happen. The children were a pleasure to work with and I am thankful to have been allowed access into their lives.

I would especially like to thank my core family: Elódia (mom), Edvaldo (dad), Lourdes (grandmother), Edílson (uncle) and Sonia, and Elizabete (aunts) for all their love, and for all the opportunities they've given me. Of course, I thank all the others relatives, but no names here. This is could be a problem in a big family. Finally, I thank CAPES (Coordination of Improvement of Higher Level Personnel, Brazil) for funding this Ph.D. project. 


\section{DARSTELLUNG DES EIGENEN BEITRAGS}

Die Idee zum Thema der Dissertationsarbeit habe ich gemeinsam mit meinem Doktorvater Prof. Dr. med. Wieland Kiess erarbeitet. Die Daten stammen aus der LIFE Child Studie (Quante et al., 2012, Poulain et al., 2017). Bei der Datensammlung und Datenbereinigung habe ich als studentische Hilfskraft mitgeholfen. Die Analyse der Daten und die Interpretation der Ergebnisse habe ich selbstständig durchgeführt. Dr. rer. medic. Diana Pietzner, Dr. rer. medic Mandy Vogel, Prof. Dr. med. Antje Körner, MUDr Ph.D Juraj Stanik und Dr. rer. nat. Anja Willenberg haben mich dabei freundlicherweise unterstützt. Die Formulierung des Manuskriptes habe ich selbst erarbeitet. Ideen und Kommentare der Co- Autoren habe ich im Verlauf eingearbeitet.

Prof. Dr. med. Wieland Kiess
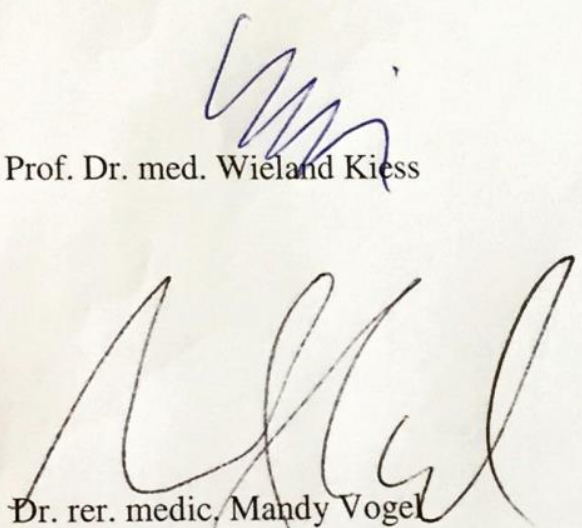

Prof. Dr. med. Ante Kümer

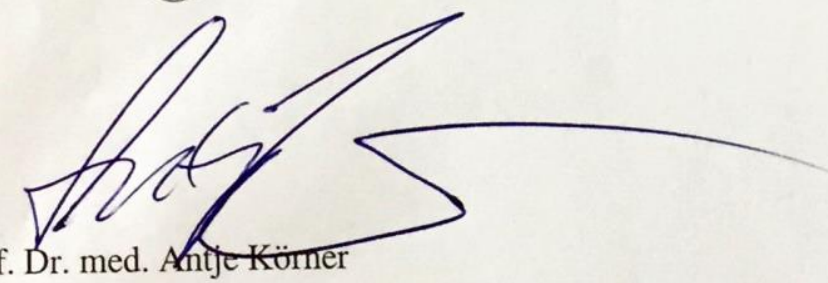

\section{MUDr Ph.D Juraj Stanik}

